\title{
Rac1, A Potential Target for Tumor Therapy
}

\begin{abstract}
Jiaxin Liang ${ }^{1 \dagger}$, Linda Oyang ${ }^{1 \dagger}$, Shan Rao ${ }^{1}$, Yaqian Han ${ }^{1}$, Xia Luo ${ }^{1}$, Pin Yi ${ }^{1}$, Jinguan Lin ${ }^{1}$, Longzheng Xia ${ }^{1}$, Jiaqi Hu ${ }^{1}$, Shiming Tan $^{1}$, Lu Tang ${ }^{1,2}$, Qing Pan ${ }^{1,2}$, Yanyan Tang ${ }^{1,3}$, Yujuan Zhou $^{1 *}$ and Qianjin Liao ${ }^{1,3^{*}}$

${ }^{1}$ Hunan Key Laboratory of Cancer Metabolism, Hunan Cancer Hospital and the Affiliated Cancer Hospital of Xiangya School of Medicine, Central South University, Changsha, China, 2 University of South China, Hengyang, China, ${ }^{3}$ Clinical Research Center for Wound Healing in Hunan Province, Changsha, China
\end{abstract}

RAS-related C3 botulinum toxin substrate 1 (Rac.1) is one of the important members of Rho GTPases. It is well known that Rac1 is a cytoskeleton regulation protein that regulates cell adhesion, morphology, and movement. Rac1 is highly expressed in different types of tumors, which is related to poor prognosis. Studies have shown that Rac1 not only participates in the tumor cell cycle, apoptosis, proliferation, invasion, migration and angiogenesis, but also participates in the regulation of tumor stem cell, thus promoting the occurrence of tumors. Rac1 also plays a key role in anti-tumor therapy and participates in immune escape mediated by the tumor microenvironment. In addition, the good prospects of Rac1 inhibitors in cancer prevention and treatment are exciting. Therefore, Rac1 is considered as a potential target for the prevention and treatment of cancer. The necessity and importance of Rac1 are obvious, but it still needs further study.

Keywords: Rac1, tumorigenesis, metastasis, cancer stemness, therapy resistance

\section{BACKGROUND}

The classical Rho-GTPase family consists of RhoA (RhoA-RhoC), Rac (Rac1-Rac3 and RhoG), Cdc42 (Cdc42, RhoJ, and RhoQ), and RhoF (RhoD and RhoF) (1). The Rho-GTPase family is involved in a variety of important cellular activities, such as acting skeleton remodeling, cell adhesion, cell movement, vesicle transport, angiogenesis, and cell cycle regulation (2-5). RhoGTPase family is called "molecular switch" because it can change between the active GTP bound conformation and GDP bound conformation. The activation of the "molecular switch" is controlled by guanine nucleotide exchange factors (GEFs), which stimulates the release of GDP and promote the combination of GTP (6). The inactive state of Rho-GTPase is maintained by the guanine nucleotide dissociation inhibitor (GDIs) and GTPase activating protein (GAPs) (7). With the changes of Rho-GTPase protein level, activity status, and effector protein abundance, the Rho signal becomes abnormal, which may affects the recombination and migration of cells (8). Rac1, Rho, and Cdc42 are the three most important characteristic members of the Rho-GTPase family, and Rac1 has received the most attention (4). Racl is widely expressed in tissues, which is considered a regulatory factor related to cell movement and invasion (9). It has been found that Racl is highly expressed and over-activated in many cancers. As an intracellular signal transducer, activated Rac1 can control many basic cellular functions, including cytoskeleton dynamics, so as to maintain cell morphology, polarity, adhesion, and migration $(10,11)$. Unbalanced expression or activation 
patterns of Racl may lead to abnormal cell signal transduction and diseases, such as cancer (4). Drug resistance is the most important reason leading to the poor prognosis of cancer patients. This is due to the formation of a special drug resistance mechanism in tumors, and Racl plays an important role in regulating drug resistance in tumor treatment (12). In a word, it is necessary to make a thorough study on Racl as an important potential therapeutic target.

\section{Rac1 REGULATES CELL ADHESION, MORPHOLOGY, AND MOVEMENT}

The Rho-GTPase family (Rho, Rac1 and Cdc42) plays an important role as cytoskeleton regulatory proteins (13), which is best confirmed in fibroblasts and can be observed in many other cell types, such as epithelial cells, endothelial cells, astrocytes and mast cells (14-16). Rac1 regulates cytoskeleton recombination, actin polymerization, and leading-edge extension by promoting actin assembly (17), which is necessary for the formation of lamellar lipid membranes and membrane folding (13). Without Rac1 and Rac2, the ability of osteoclasts to form actin cytoskeleton is insufficient (18).

Actin polymerization regulated by Rac1 and Cdc42 can promote cell movement, leading to migration and invasion (19). The migration of cancer cells is closely related to the decrease of cell adhesion, rearrangement of cytoskeleton, degradation of the extracellular matrix and the formation of cell surface protrusions, which are the key factor affecting the migration of cancer cells (20). Extension of cytoplasm in the movement direction is the first step of cell movement. In the process of long-distance extension of cells, it is necessary to protrude a wide and flat flaky prosthetic foot on the cell surface, and Racl is needed to form this structure $(21,22)$. The finger-like structures formed in lamellipodium is called filopodia, which is regulated by $\mathrm{Cdc} 42$ and participates in cell adhesion (23). Due to different environments, migrating cells present morphological differences (such as expansion, contraction and polarization), which are controlled by the activity levels of cytoskeleton regulatory protein Rho-GTPase (24). CYRI/FAM49B (CYFIPrelated Rac1 interacting protein) negatively regulates Rac1driven cytoskeletal remodeling (25). The dynamic structures of axonal endings in neuroblastoma cell line N1E-115 was activated by Rac1 and Cdc42 (26). The depletion of estrogen receptor $\alpha$ $(\mathrm{ER} \alpha)$ affects the biomechanical properties of Breast cancer (BC) cells, which is related to the decrease of cytoskeletal proteins (Factin, FLNA, and $\alpha$-tubulin) and cytoskeletal regulatory proteins (Rho, Rac1, and Cdc42) (27). Introducing the mutant Rac1 (P29s) into normal melanocytes can increase membrane folding, and promote proliferation and migration of melanocytes (28). The Rac1 mutant (P29s) melanoma cells can up-regulate the formation of platelet lipoprotein through dendritic actin polymerization (29). When the integrinassociated kinase gene is inactivated in mature melanocytes, motility and dendritic defects occur, which are recovered in the presence of Racl (30). Urobilin A (UA), a metabolite of intestinal bacteria, inhibits cell proliferation and migration through destroying the activities of Rac1 and PAK1 (31) (Figure 1).

The most mature mechanism of Racl mediated cytoskeletal recombination is through PAKs (P21 activated kinase) (32). Both cell proliferation and cell movement require actin recombination, which is controlled by Racl and PAK1 (31). PAKs can be divided into two groups: one is PAK 1-3 and the other group is PAK 4-6 (33). The C-terminal kinase domain of PAK subgroup I is a highly conserved sequence, which can exert its biological activity by binding Cdc42 or Rac1 (34). PAK1 is an important downstream effector of Racl and Cdc42 (35). Rac1 and Cdc42 can activate LIM kinase1 (LIMK1) through PAK, which leads to the decrease of cofilin activity and enhance mobility through phosphorylation (36). The effect of PAK on cell mechanics depends on Rac1, and the formation of the Rac1PAK pathway plays an important role in cytoskeleton reorganization during cell migration (19). Abnormal high expression of non-receptor tyrosine kinase FER is the key to metastasis of ovarian tumor cell in vitro and in vivo (37). When FER is knocked out, the Rac1-PAK1 signaling pathway is inactivated and the migration ability of ovarian cancer cell CAOV4 decreased (38). Knocking down PKC-can lead to a decrease in the proliferation and metastasis of colorectal cancer (CRC) cells because $\mathrm{PKC}-\zeta$ reduces the nuclear translocation of $\beta$-Catenin and affects the Rac1-PAK1- $\beta$-catenin signaling cascade (39).

\section{THE EXPRESSION AND CLINICAL SIGNIFICANCE OF Rac1 IN TUMORS}

The malignant transformation of tumor is mainly related to over-activation or over-expression of Rac1. Up to now, the increase of Racl expression has been detected in different types of cancers, such as BC, lung cancer, colorectal cancer, gastric cancer, prostate cancer, hepatocellular carcinoma and ovarian cancer (40-46). The activity of Racl is also related to many posttranslational modifications, such as phosphorylation (Tyr64, Ser71), ubiquitination (Lys147, K166R), lipidation, and adenylation (Y32) (47-53). Rac1 usually does not mutate, except in certain cancers, such as melanoma. Rac1 (P29S) is the third most common mutation codon in human skin melanoma, affecting 4-7\% of patients (28) (Figure 2).

The mutant form of Rac1 (N92I) found in human sarcoma cell line HT1080 not only makes Racl highly carcinogenic, but also resists endoplasmic reticulum stress $(54,55)$. The mutants of Rac1 (P29S) or (N92I) can improve the level of the active binding status (Rac1-GTP) by promoting the decomposition of the intrinsic inactive binding status (Racl-GDP) of Racl, thus forming a "spontaneous activation" state, which strongly promotes the occurrence of tumors $(54,56)$. Other forms of Rac1 mutants are also found in other tumors, such as the Rac1 (A159V) mutation common in Head and Neck Neoplasms and the Racl (Q61R) mutation in primary prostate cancer $(57,58)$. The expression of Racl protein in different tumor tissues was 


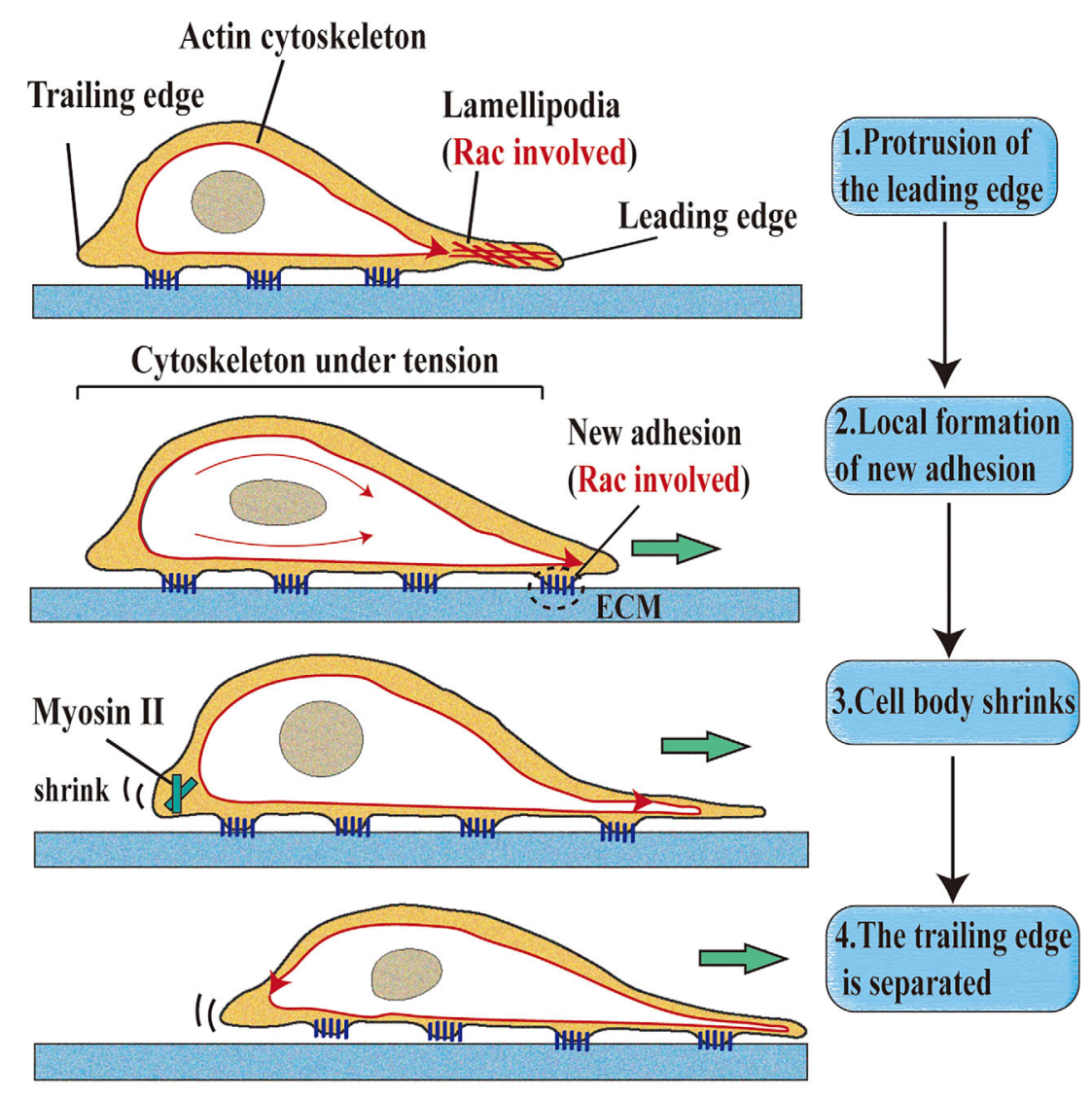

IIII Integrins F-actin Myosin II

FIGURE 1 | Roles of Rac1 in single-cell migration. Single-cell migration is a multi-step process. 1. Protrusion of the leading edge: Rac1 is located at the leading edge of the cell, remodels the actin cytoskeleton to form lamellipodia, and directs cell migration.; 2. Local formation of new adhesion: integrity contact with extracellular matrix (ECM) ligand and cluster in the cell membrane (Rac1 involved); 3. Cell body shrinks: Myosin II is responsible for shrinking the trailing edge of cells; 4. The trailing edge is separated: The contractile force generated by the actomyosin structure can make the cell movement translation.

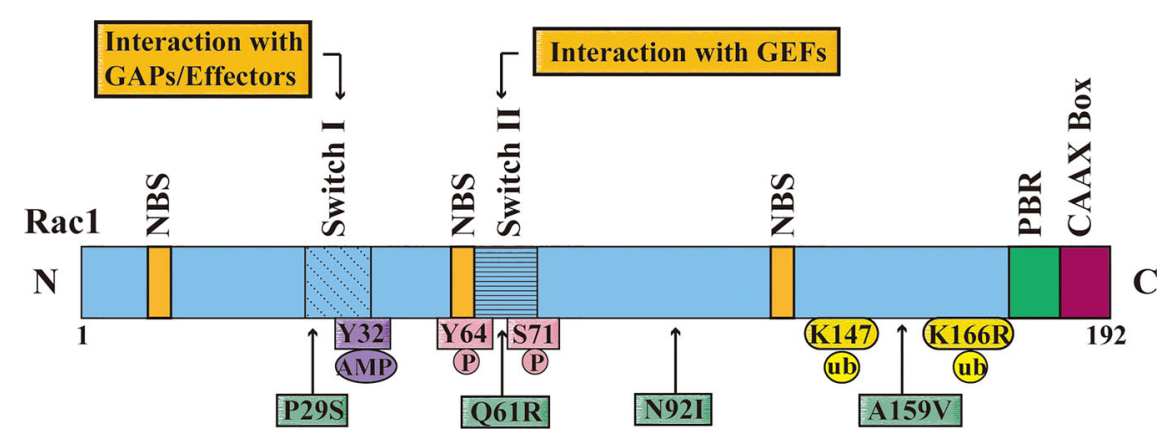

FIGURE 2 | The domain, post-translational modifications and mutation sites of Rac1. The figure shows that the different domains of Rac1 including nucleotidebinding site (NBS), switch I, switch II, multi-base region (PBR), and CAAX box. Switch I mainly interacts with the downstream effectors of RAC1, and Switch II interacts with the RAC1 activation protein guanine nucleotide exchange factor (GEF). The figure also shows the Rac1 adenylation site (Y32), phosphorylation sites (Y64 and S71), and ubiquitination sites (K147 and K166); and important missense mutations of Rac1 (P29S, Q61R, N92I and A159V) are displayed with a green frame, and the position is pointed out with an arrow. 
detected by immunohistochemistry. It was found that the high expression of Racl protein was closely related to the differentiation, staging and lymph node metastasis of tumor $(59,60)$. The analysis and detection of renal cell carcinoma (RCC) samples showed that Racl protein was highly expressed, which was positively correlated with the poor clinical prognosis of RCC (61). The expression of Rac1 in gastric cancer tissues was detected, and it was found that the expression of Rac1 in TNM III and IV stages was higher than that in I and II stages and was associated with tumor lymph node metastasis (62). When epithelial ovarian cancer, primary gallbladder cancer (PGC) and hepatocellular carcinoma are analyzed, the same conclusion is reached $(40,63,64)$. According to bioinformatics analysis, it was found that the overexpression of Rac1 and RRM2 was closely related to the poor prognosis of HER-2 positive BC patients (41). In the analysis of miRNA related to gastric cancer metastasis, it was found that the high level of miR-345 was positively correlated with the good prognosis of patients, because miR-345 down-regulated the transmission of epidermal growth factor receptor pathway substrate 8 (EPS8) and Rac1 signal (65). $\mathrm{HACE} 1$ is a ubiquitin ligase of E3. In lung cancer and prostate cancer, the low expression of HACE1 can make Racl overactive, which is related to the shortened survival time of tumor $(66,67)$. A meta-analysis shows that high expression of Racl could predict the poor prognosis of cancer patients (68). Therefore, abnormal expression of Racl can be used as a monitoring index for the progression and poor prognosis of different types of cancers.

\section{REGULATION OF Rac1 IN TUMOR PROGRESSION}

The inactive state of Racl can combine with various effector proteins and regulate cell events, such as cell cycle, cell proliferation, apoptosis, stem cell characteristics of cancer cells, and neovascularization, thus participating in the occurrence and development of cancer $(3,56,69,70)$.

\section{Rac1 Participates in the Cell Cycle, Apoptosis, and Proliferation}

Rac1 shuttles between cytoplasm and nucleus during the whole cell cycle, and accumulates in nucleus in the late G2 stage (71). And the induction of the G1 cell cycle by Racl is independent of the JNK/SAPK MAP kinase cascade (72). Racl overexpression activates the $70 \mathrm{kDa}$ ribosomal S6 kinase (pp70S6k), which plays an important role in the G1 phase of the cell cycle (73). Overexpression of ARHGAP24 significantly inhibits the activities of RhoA and Racl and induced apoptosis of lung cancer cells via STAT6-WWP2-p27 axis (74). Rac1 participates in the formation and elimination of apoptotic cells and coordinates receptor signals related to apoptosis and proliferation $(75,76)$. In B-cell lymphoma, Rac1 was found to be a new binding partner of Bcl-2, which can stabilize its antiapoptosis activity (77). It has been confirmed that the regulation of chromosome condensation 2 (RCC2) on apoptosis is mediated by inhibiting Racl signal transduction (78). Racl can also form miR-506-rock2-rac1 signal axis with mir-506 and ROCK2 (Rho protein kinase 2), and participate in the proliferation and apoptosis of hepatocellular carcinoma (HCC) cells (79). The apoptosis of glioma cells induced by Rac1 inhibition can be partly saved by mitogen-activated protein kinase 1 , which is the activator of JNK (80). Lionarons et al. further revealed that Rac1 (p29s) can activate the gene expression program initiated by the PAK, AKT and SRF/MRTF transcription pathways. It can induce melanocytes to transform into mesenchymal-like cells, inhibit apoptosis, and enhance tumorigenesis (81). OPA interacting protein-5 (OIP5) regulates proliferation, apoptosis and cell cycle of HCC cells by influencing BMPR2-JUN-CHEK1-Rac1 signal axis (82).

\section{Rac1 Promotes Tumor Angiogenesis}

Angiogenesis is one of the hallmarks of malignant tumors. Overexpression of Racl is related to the high levels of vascular endothelial growth factor (VEGF) and vascular endothelial growth factor receptor (VEGFR) can form a VEGF-VEGFR signaling pathway, which participates in the regulation of angiogenesis (83, 84). The role of Racl in retinal angiogenesis has been well documented $(85,86)$. IQ- guanosine triphosphatase activating protein 1 (IQGAP1) is a scaffold protein with Rac1 binding domain, and its knock-out can significantly inhibit choroidal neovascularization induced by the VEGFR2-Rac1 signal axis (87). Sphingosine-1 phosphate receptor1 (S1PR1) can amplify the angiogenic signal of VEGF-VEGFR2, thus maintaining the activity of Racl and promoting the growth of tumor (88). Sevoflurane, a volatile anesthetic agent, exerts an anti-angiogenic effect by inhibiting the signal transduction of Rac1-paxillin-FAK and Ras-Akt-mTOR (89). M1 macrophage-derived exosomes (M1-Exos) inhibit the Rac1PAK2 signaling pathway and decrease the angiogenesis ability of endothelial cells (ECs) (90). In mouse models, it has been found that the activation of PAK1 by endothelial Racl is helpful for post-stroke recovery and angiogenesis (91). NCK1, an adaptor with Src homologous domain, can promote the angiogenesis of cervical squamous cell carcinoma (CSCC) through the Rac1-PAK1-MMP2 signaling pathway (92). In the study of aristolochic acid-induced nephropathy, it was found that over-expression of NCK1 can not only restore the decrease of Racl activation, but also save the damaged angiogenesis (93). Tomm7 (translocase of outer mitochondrial membrane 7) gene is selectively inactivated, which induces an increase in the entry of Racl into mitochondria, and promotes the redox signal transduction coupled with mitochondria Rac1, which leads to cerebrovascular disorders and affects the homeostasis of the cerebrovascular network (94).

\section{Rac1 Participates in Tumor Migration and Invasion}

Overexpression of Racl enhances cell proliferation and migration, and plays an important role in the invasion and migration of many tumor cells (65, 95-99). Atypical protein kinase $\mathrm{C}-\zeta(\mathrm{PKC}-\zeta)$ mediates $\mathrm{BC}$ cell invasion through Racl and RhoA pathways (100). A high concentration of stromal cellderived factor $1-\alpha$ (SDF-1 $\alpha$ ) promotes the expression of Rac1 and mediates the migration and adhesion of BC cells (101). The 
ability of the oral contraceptive centchroman (CC) to inhibit migration and invasion of $\mathrm{BC}$ cells is achieved by inhibiting the Rac1-PAK1- $\beta$-catenin signal axis (102). The stimulation of NF- $\kappa B$ by Racl partly regulates the proliferation and invasion of the melanoma cell line FEMX (103). Our research team found that Rac1 was significantly up-regulated in metastatic colorectal cancer tissues, and the overexpression of Racl can significantly promote the migration and invasion of colorectal cancer cells (43). We have further found that diallyl disulfide (DADS) inhibits the migration and invasion of colorectal cancer cell line SW480 by regulating the Rac1-ROCK1/PAK1-LIMK1-ADF/cofilin signaling pathway (104, 105). Zhang, et al. found that Plastin1 (PLS1), which is related to the microvilli structure of the intestinal epithelium, drives the metastasis of colorectal cancer through the IQGAP1-Rac1-ERK pathway (106). Overexpression of phospholipid phosphataserelated protein 1 (PLPPR1) in the mouse neuroblastoma cell line (Neuro2a) reduces the level of active Rac1. Therefore, it can lead to increased cell adhesion and decreased cell migration (107). miR142-3p inhibits the migration of bladder cancer cells through Rac1 (97). The long non-coding RNA LCAT1 is a competitive endogenous RNA of miR-4714-5p, which leads to the upregulation of the activity of its endogenous target Racl and promotes the growth and invasion of lung cancer cells (96).

Epithelial-mesenchymal transition (EMT) is another important characteristics in the process of tumor cell metastasis. Cells undergoing EMT will lose their cell polarity and adhesion between cells, which is related to the reorganization of the cytoskeleton structure (108). Rab23 is a member of the Rasrelated small GTPase family, which can activate Racl-TGF $\beta$ signal transduction and promotes EMT in HCC cells (109). POTEE, a member of the POTE anchor protein family E, promotes invasion and migration of colorectal cancer and EMT by promoting the activation of Racl and Cdc42 (110). miR-331-3p targets ErbB2 and Vav2 through the Rac1-PAK1- $\beta$-catenin axis to inhibit EMT, migration and metastasis of non-small cell lung cancer (NSCLC) cells (111). Tualang honey in the jungle of Malaysia maintains the epithelial polarity of cells by overexpressing $\beta$-catenin and E-cadherin, and inhibits the invasiveness of oral squamous cell carcinoma (OSCC) by downregulating TWIST1 and Rac1 (112). Our previous experiments confirmed that Racl can influence the expression of EMT-related molecules, and participate in the invasion and metastasis of CRC (43). Guanine nucleotide exchange factor $\mathrm{T}$ (GEFT) affects the occurrence of EMT and interstitial transformation (MET) in rhabdomyosarcoma (RMS) cells through the Rac1-Cdc42-PAK1 (113). miR-142-3p affects the expression of Racl at the protein level, thus inhibiting the phosphorylation of PAK1 and EMT in BC cells (114).

\section{Rac1 Functions in Cancer Stem Cells}

The stemness of tumor cells is considered to be a key factor in tumor initiation, progression, and recurrence. Racl is involved in the regulation of stem cell characteristics of various tumor cells. Rao, et al. found that Rac1 participates in semaphorin-3F (Sema3F) -mediated CRC cell stemness regulation by targeting the classical Wnt- $\beta$-catenin pathway (115). Rac1 can participate in the regulation of intestinal stem cell proliferation and the occurrence of colorectal cancer through the activation of Wnt pathway by NF- $\mathrm{KB}$ or in a ROS-dependent manner $(116,117)$. Integrin can activate the Racl signaling pathway in stem cells, and thus stimulate Wnt pathway. Integrin- $\beta 1 / \mathrm{Rac} 1$ signal plays an important role in the maintenance and self-renewal of mammary epithelial stem cells (118). The expression of integrin- $\alpha 5$ (ITGA5) is down-regulated by miR-205, which can inhibit the stem cell characteristics of triple negative breast cancer (TNBC) through the Src-Vav2-Rac1 pathway (119). However, Carmon, et al. found that LGR5 (containing the leucine-rich repetitive sequence of $G$ protein-coupled receptor 5) mainly activates the IQGAP1-Rac1 pathway, but not Want signaling pathway, so as to promote cell adhesion between stem cells and colon cancer cells (120). LncRNA NR2F2-AS1 mediated the up-regulation of Rac1 expression can increase the cancer stemness of clear cell renal cell carcinoma (ccRCC) cells (121). Inhibition of $\beta 2$-chimaerin protein mediated by hippocampus effector TAZ leads to the persistence of Rac1 activity in cancer stem cells (CSCs) (122). Semaphorin-3C (Sema $3 \mathrm{C}$ ) is involved in promoting the survival and tumorigenicity of glioma stem cells by activating Rac1, which is related to activating Rac1-NF- $\kappa B$ signal $(123,124)$. Inhibition of Racl can block the proliferation and metastasis of NSCLC tumor stem cells (125). Both miR-365 and miR-194 can inhibit the dedifferentiation of HCC cells and the proliferation of HCC stem cells by targeting Racl signals $(126,127)$. In addition to endowing tumor cells with the ability of migration and invasion, EMT can also make highly invasive tumor cells acquire stem cell-like characteristics and promote the production of CSCs (128). In NSCLC, inhibiting Rac1 activated during EMT can inhibit the dynamic transformation between cancer stem/progenitor cells (CS/PC) and non-CS/PC (129). DJ001 is a receptor-type protein tyrosine phosphatase-sigma (PTP $\sigma$ ) inhibitor, which can inhibit radiationinduced apoptosis of hematopoietic stem cells (HSCs), and promote the regeneration of HSC by activating Racl and inducing the expression of Bcl-xl (130).

In recent years, the mechanism of Racl involved in the regulation of different tumorigenic phenotypes has been elucidated. As an important goal of cancer prevention and treatment, the relationship between Racl and tumorigenesis, proliferation, metastasis, and development of drug resistance has gradually become clear. Although we already know that Rac1 plays an important role in cancer, there are few clinical studies related to Rac1, and the detailed mechanism of Racl participating in cancer has not yet been clarified. The synergistic effect of Racl and other carcinogens is particularly reflected in the intersection of signal pathways, which needs further exploration (Figure 3).

\section{Rac1 Is Involved in the Regulation of Resistance to Tumor Therapy}

The application of molecularly targeted drugs has greatly improved the clinical efficacy of cancer treatment. However, with the progress of treatment, acquired drug resistance appears, which greatly reduces the treatment effect and even leads to failure. The development of molecular targeted drug 


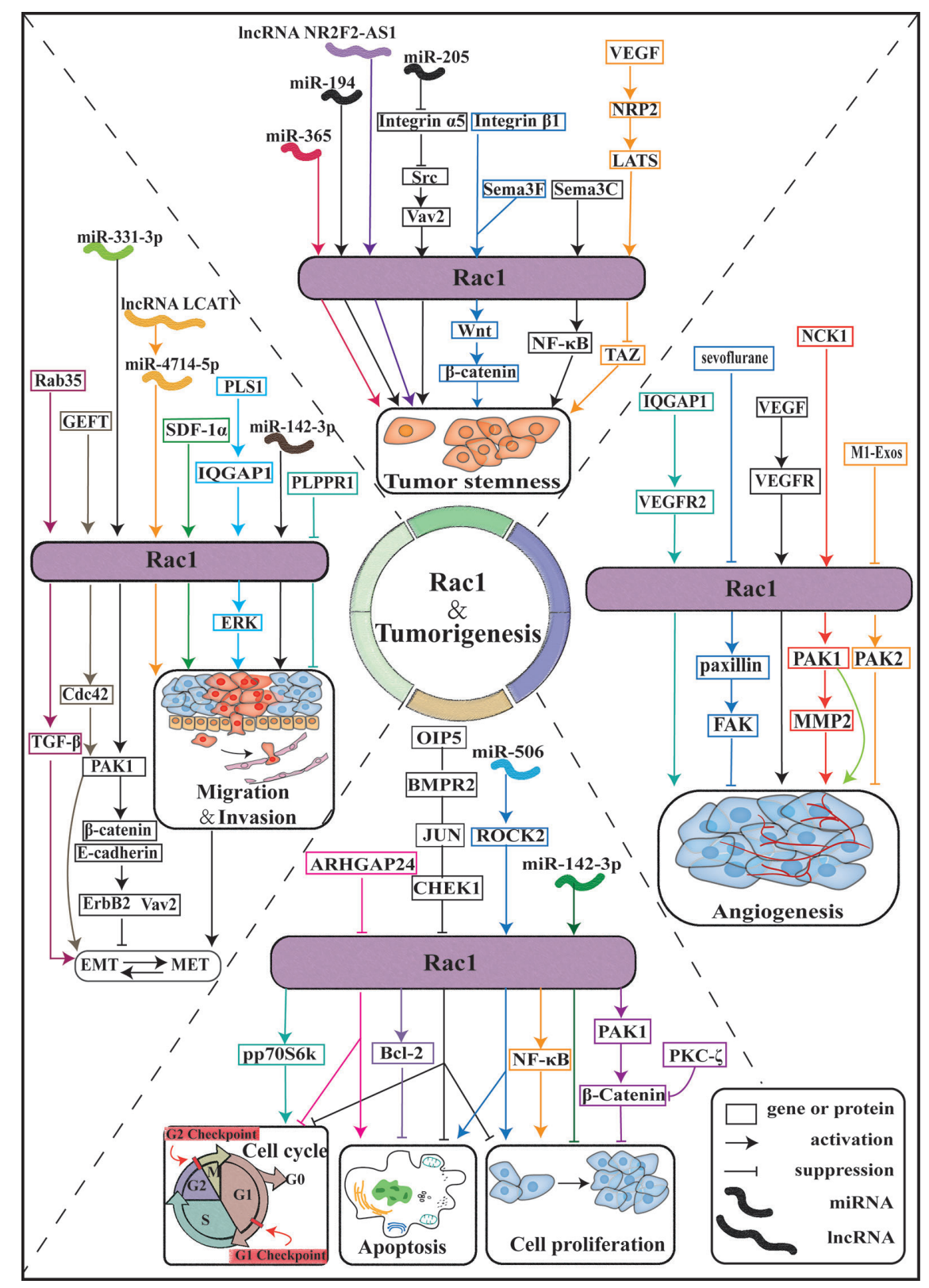

FIGURE 3 | Rac1 is involved in tumorigenesis. Schematic diagram of the Rac1 signaling pathway and effectors. The Rac1 signaling pathway plays an important role in the pathobiology of various tumor progression processes, including tumor cell proliferation, cell cycle, apoptosis, tumor cell invasion, and migration, tumor angiogenesis, and tumor cell stemness. ARHGAP24: Rho GTPase activating protein 24; PKC- $\zeta$ : protein kinase C- $\zeta$; PAKs: p21 activated kinase; M1-Exos: M1-type macrophage-derived exosomes; IQGAP1:IQ-guanosine triphosphatease-activating protein 1; SDF-1 $\alpha$ : stromal cell-derived factor 1- $\alpha$; Sema3F: semaphorin-3F;

Sema3C: Semaphorin-3C.

resistance is closely related to cancer as a dynamic and highly heterogeneous disease. This is because the heterogeneity of cancer not only drives the development of cancer, but also affects drug resistance, which provides a driving force for the drug resistance of cancer treatment $(131,132)$. In addition, mutations of the drug target gene and the enhancement of DNA damage repair ability are also the important mechanisms for drug resistance $(133,134)$. Therefore, the analysis of the mechanism of drug resistance is helpful to find effective targets to overcome drug resistance, to better select effective treatment methods for patients and to improve prognosis.

The increase of Racl expression is one of the characteristics of drug-resistant cells (135). The instability of the genome leads to an increase in mutation rate, and then promotes the development of cancer, which affects drug resistance through various mechanisms. Taking melanoma as an example, Rac1 is 
an important somatic-driven mutation gene in melanoma (136). Melanoma is mostly treated with inhibitors of the MAPK signaling pathway that targets BRAF or MEK kinase (137). However, the treatment response rate in the middle and late stages of treatment is not high, which may be due to the reactivation of the MAPK signaling pathway and/or the activation of the PI3K-AKT pathway caused by selected genetic changes before or during treatment, which caused the primary and acquired resistance (138). BRAF600E and Rac1P29S are hot spot mutations in melanoma. MAP kinase pathway inhibitor (MAPKi) is effective for melanoma patients with BRAFV600E mutation. According to the understanding of MAPKi resistance mechanism, it was found that CUL3, the key protein in the E3 ubiquitin ligase complex, participated in vemurafenib resistance mechanism by enhancing Racl activity and MEKS 298 phosphorylation. Furthermore, it was found that the Src family inhibitor Saracatinib can inactivate Rac1, thereby inhibiting MAPKi resistance phenotype (139). Rac1P29s was found to confer resistance to BRAF/MEK inhibitors (BRAFi/MEKi) to melanoma cells (140), which can be reversed by SRF/MRTF inhibitor (81). When drug resistance occurs in tumors, the endogenous metabolic profile changes significantly, and Racl is involved in it. $\mathrm{Li}$, et al. showed that targeting Racl can effectively reduce the multidrug resistance of $\mathrm{BC}$ cells to neoadjuvant chemotherapy (NAC). This is because Racl activates aldolase A (ALDOA) and ERK signaling, thereby up-regulating glycolysis, especially the non-oxidized pentose phosphate pathway (PPP), which leads to the enhancement of nucleotide metabolism (141). Rac1 silencing can also inhibit AKT-FOXO3a signal and cell glycolysis enzymes, so as to overcome cisplatin resistance in esophageal squamous cell carcinoma (ESC) (142).

The expression of Racl regulates the sensitivity of cancer to chemotherapy (143). Targeting the Rac1 pathway can overcome the resistance of NSCLC patients to EGFR-TKI, and it works independently of the MEK or PI3K mechanism (144). Silencing of cadherin 2 (DSG2) can inhibit the EGFR-Src-Rac1-PAK1 signaling pathway and increase resistance to osimertinib (145). In multidrug-resistant lymphoma cell lines expressing a higher levels of Tiam1, the researchers found that dual inhibition of Tiam1-Rac1 and Notch pathways would be an important treatment for overcoming the resistance of lymphoma cells to adriamycin (146). Hofbauer, et al. found that inhibition of Tiam1-Rac1 signaling can antagonize the chemical resistance of chronic lymphocytic leukemia (CLL) cells to fludarabine (147). YAP, a key effector of the Hippo pathway, confers multidrug resistance to HCC cells by up-regulating the Rac1-ROS-mTOR pathway, which leads to the inhibition of autophagy-related cell death (148). Similarly, Rac1 also affects the sensitivity of cancer to radiotherapy. RP-4, a new type of radiosensitizer derived from rhein, activates the sensitivity of nasopharyngeal carcinoma (NPC) cells to radiotherapy by targeting the Rac1-NADPH pathway (149). Our research team has confirmed that Racl can target the PAK1LIMK1-Cofilins signaling pathway to cause radiotherapy resistance in lung cancer (150). In the treatment of head and neck squamous cell carcinoma (HNSCC), it was found that the combination of Rac1 inhibitors based on radiotherapy can improve the therapeutic effect
(151). Inhibition of Rac1 with specific inhibitors of Rac1 not only eliminates the activation of G2 checkpoints induced by radiotherapy (IR) but also improves the sensitivity of pancreatic cancer cells to radiotherapy by inducing apoptosis (152). It is evidenced that inhibition of Racl activity can be used to overcome treatment resistance, which has also been confirmed in cisplatin-resistant gastric adenocarcinoma cells (153) and trastuzumab-resistant BC cells (154).

As shown before, Rac1, as an important "commander" of drug resistance in tumor therapy, regulates the drug resistance of tumor cells to targeted drugs by participating in various mechanisms and thus affects the sensitivity of tumor cells to radiotherapy and chemotherapy. However, although Racl may be a useful target for overcoming drug resistance, the mechanism of each has not been clearly explained $(136,155)$, and it is necessary to explore how Rac1 participates in the resistant mechanism. It is worth mentioning that the regulatory mechanism of Racl on the endogenous metabolic profile in the development of drug resistance can be further explored. Using evolutionary thinking to deal with drug resistance is an important way to deal with heterogeneity and evolutionary drug resistance of tumors. It is also worth noting that the combined treatment of targeted Rac1, radiotherapy, and chemotherapy combined with Rac1 inhibitor may be a reasonable and reliable solution to improve the sensitivity of tumor cells to radiotherapy and chemotherapy and overcome the drug resistance of tumor cells to targeted drugs (Figure 4).

\section{Rac1 Participates in Tumor Microenvironment-Mediated Immune Escape}

Tracing back to the "seed and soil" hypothesis published by Paget in the 19th century, we know that the occurrence and development of tumors depend not only on the tumor cells themselves but also on the environment in which tumors depend, that is, the tumor microenvironment. The tumor microenvironment is mainly composed of various infiltrating immune cells and other interstitial cells, as well as a variety of secretory factors. With the development of the tumor, the tumor microenvironment changes the immune microenvironment by recruiting or amplifying a variety of immune heterogeneous cells, blocking the effective immune monitoring ability of hosts and mediating immune escape.

There is some correlation between Racl and immunity (156, 157). Racl regulates the immune homeostasis of the liver, which may exist as an immune checkpoint (158). The activation of Rac1 can drive the pathogenic interaction between epithelial cells and the immune system, which is also the pathological basis of psoriasis (159). Rac1 and Rac2 play a role in the regulation of $\mathrm{B}$ cell humoral immune response and in vitro Ig class switching (76). Rac1 forms a complex with Tiam1 and regulates the transcription of interleukin 17A (IL17A) and autoimmunity (160). TNFAIP8L2/TIPE2 (tumor necrosis factor, alphainduced protein 8-like 2) can directly bind to and block Rac1 GTPase activity, thereby regulating innate immunity (161). PI3K activates immunity by up-regulating IL-10 and inhibiting proinflammatory cytokines, possibly through the regulation of Rac1 protein (162). Withanolides, as immunopotentiators and 


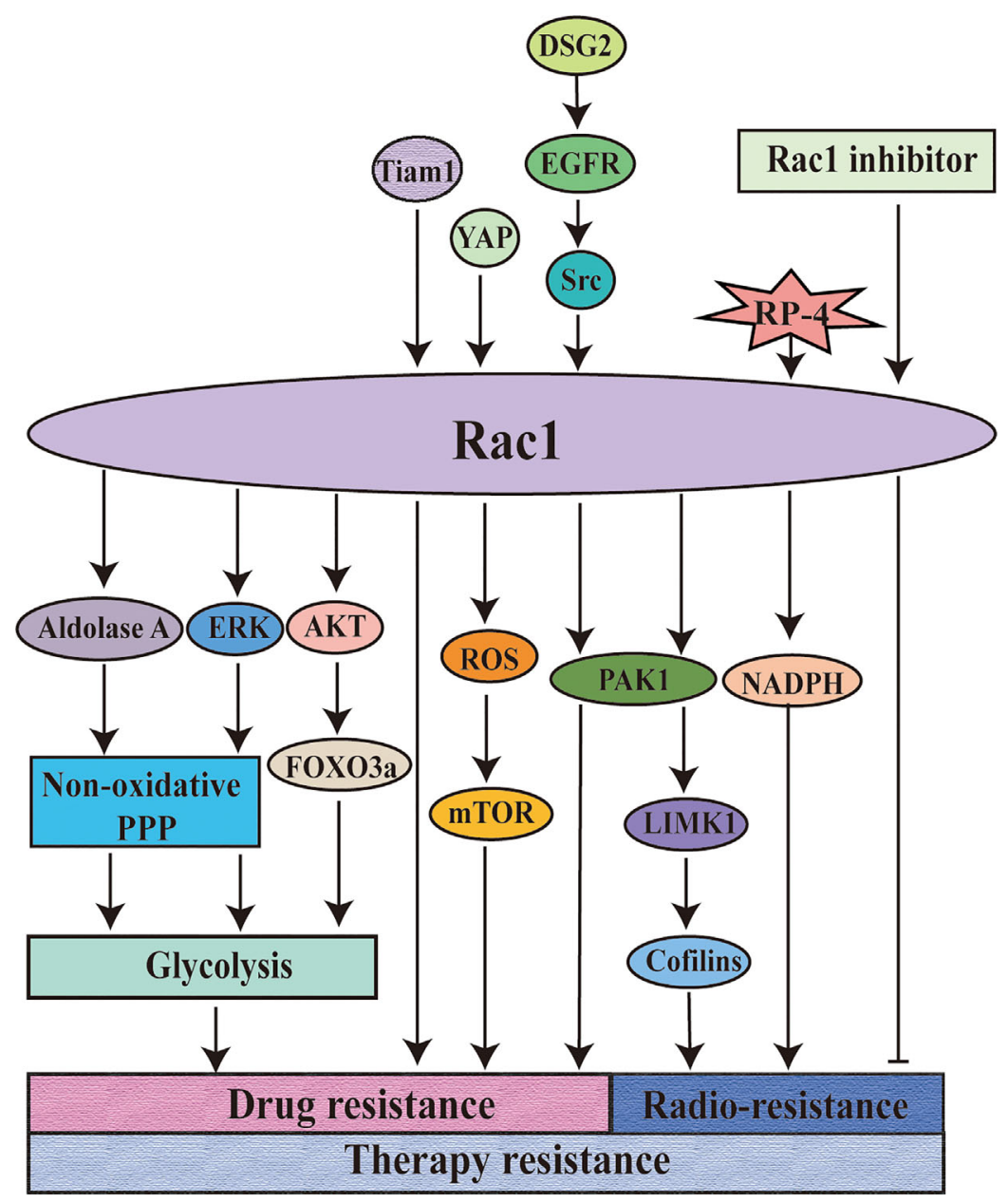

FIGURE 4 | Rac1 is involved in the regulation of resistance to tumor therapy. Rac1 is involved in the regulation of tumor treatment resistance. Targeting Rac1 can improve the sensitivity of the tumors to chemotherapy and overcome the drug resistance of the tumors to molecularly targeted drugs. The combined application of Rac1 inhibitor on the basis of radiotherapy can significantly improve the therapeutic effect. DSG2: cadherin 2.

antiviral agents against COVID -19, may play a role by targeting the Racl protein (163). Compared with Racl WT, melanoma cells with Rac1(P29S) mutations express high levels of PD-L1 and therefore have the ability to evade immune surveillance (164). The use of lenalidomide, an immunomodulatory drug, can restore the normal activity levels of Rac1, RhoA, and Cdc42 in T cells of patients with chronic lymphocytic leukemia (CLL), and preserve the adhesion and movement ability of $\mathrm{T}$ cells and the function of integrin lymphocyte activation-related antigen 1 (LFA-1) (165). Therefore, targeted inhibition of Rac1 in tumor cells may be a way to prevent immune escape, and may also be used as immune checkpoint inhibitors (ICIs).

\section{GENERAL Rac1 INHIBITOR}

Guanine nucleotide exchange factors (GEFs) are responsible for the activation of Rac1. Up to date, more than 70 GEFs related to Rac1 activation have been confirmed. GEFs are related to tumorigenesis, but the specific regulatory mechanism is still unclear, and different GEFs have different abilities to activate Rho family GTPases. The Racl inhibitor developed for the interaction between GEF and Racl is an important strategy for finding clinical drug candidates. As an inhibitor of Rac1, its most essential role is to inhibit the tumorigenicity mediated by Rac1 and the malignant biological behaviors of different tumor cells, such as cell migration, cell invasion, and rearrangement of actin skeleton $(166,167)$.

As the first specific Rac1 inhibitor, NSC23766 targets Rac1 activation through GEFs (Trio or Tiam1) but does not interfere with the binding or activation of the closely related targets Cdc42 or RhoA $(168,169)$. The seven residues on Rac1 are very important for the interaction of NSC23766 and Tiam1 (170). It has been found that NSC 23766 can inhibit the invasion and migration of human HCC by inhibiting the CAMSAP2dependent Rac1/JNK pathway, or the cysteine-rich domains-1 (LMCD1)-Rac1 pathway $(171,172)$. The inhibition of Rac1 by NSC23766 can regulate NF- $\kappa \mathrm{B}$ activity, cell proliferation, and 
cell migration in NSCLC cells (166). EHop-016 is a derivative of NSC23766. Compared with the parental compound, EHop-016 has a lower $\mathrm{IC}_{50}$. EHop-016 inhibits the binding of active Vav2 to the nucleotide-free Racl (G15A) mutant fusion protein and inhibits the activity of the downstream effector p21 activated kinase (PAK), valve foot extension, and cell migration in metastatic cancer cells (173). EHop-016 can also reduce the activity of Akt and Jun kinase (JNK) and the expression of c-Myc and Cyclin D, and increase the activity of caspase $3 / 7$ in metastatic cancer cells, thereby affecting cell survival (174, 175). EHop-016 can eliminate the growth, metastasis, and selfrenewal ability of gallbladder cancer cells caused by overexpression of miR-365 (176). Unlike NSC23766, EHT1864 was initially described as a small molecule, which interfered with the binding of nucleotides to Racl and prevented the binding of GTPase to downstream effectors $(177,178)$. The growth inhibition of BC cells induced by EHT1864 is related to the dual inhibition of PI3K-AKT-mTORC1 and MEK-ERK pathways (179). Studies have shown that Rac1 plays an important role in the contraction of various smooth muscles, such as bronchial smooth muscle, bladder smooth muscle, and prostate smooth muscle (180-183). Although both EHT1864 and NSC23766 are Rac1 inhibitors, they have different pharmacological mechanisms in the inhibition of different smooth muscles $(182,184,185)$, and EHT1864 tends to perform better $(186,187)$. In recent years, new Rac1 inhibitors have been continuously developed. ZINC69391 is a specific Rac1 inhibitor, which interferes with Rac1-GEF interaction by masking Trp56 residue on Rac1 surface. The 1A-116 analog is a Rac1 inhibitor designed and developed based on ZINC69391. It plays a role by inhibiting the interaction of Racl with the Vav family (Vav13), Tiam1, and $\mathrm{Dbl}$ (188). Trp56 is necessary for 1A-116 to play an inhibitory role (189). ZINC69391 and 1A-116 can inhibit the interaction of Rac1 and GEF (Tiam1, Dock180) (188, 190, 191). It has been found that 1A-116 and its parental compound ZINC69391 can inhibit the proliferation, invasion, migration, and cell cycle of BC cells, glioma cells, and leukemia cells, and 1A-116 shows higher specificity and intensity in vivo and in vitro $(190,191) .1 \mathrm{D}-142$ is a newly discovered new guanidine inhibitor, which can inhibit the activation of Racl by interfering with the interaction of Rac1Tiam1, and its effectiveness in vivo and in vitro is much higher than that of the reported derivative 1A-116 (192). In HCC mouse model, 1D-142 was found to significantly reduce tumor growth and intrahepatic metastasis (193). Similarly, in mouse models of NSCLC, 1D-142 was found to inhibit NSCLC cell proliferation and migration by reducing Rac1-mediated TNF $\alpha$-induced NF- $\kappa B$ nuclear translocation (192).

In the process of exploring Racl inhibitors, there are many gratifying discoveries: for example, the inhibitory effect of NSC23766 on Rac1 can antagonize the drug resistance of tumor cells to targeted drugs, such as fludarabine resistance of chronic lymphocytic leukemia (CLL) cells (147), fluorouracil and cisplatin resistance of gastric adenocarcinoma cells (153), and trastuzumab resistance of BC cells (154). NSC23766 increases the antiproliferative effect of erlotinib on glioblastoma cells in a synergistic manner (167). EHop-016 was found to be an effective inhibitor of human and mouse leukemia cells, but NSC23766 does not have the ability, which may be related to the specific targeting of EHop-016 to Vav1 (194). ZINC69391 and 1A-116 can selectively induce apoptosis of leukemia cells from patients, which may be related to significant activation of caspase- 3 and loss of mitochondrial membrane potential (191). This suggests that the combination of drugs targeting Racl and other therapeutic drugs may provide a new direction for the treatment of leukemia. EHT1864 can inhibit the proliferation of BC cells induced by increased transcription activity of estrogen receptor- $\alpha$ (Er $\alpha$ ) (195). The pharmacological inhibitory effect of 1A-116 on the Rac1-PAK1 axis, inhibition of PAK1 activity and reduction of the level of estrogen receptor phosphorylation at Ser305, is beneficial to the recovery of drug resistance mechanisms in endocrine therapy (196). Gonzalez, et al. confirmed that 1A-116 can also inhibit the Rac1 (P29S) mutation of melanoma (189). EHT1864 can block the Rac1-dependent processing of amyloid precursor protein, and amyloid precursor protein forms senile plaque of Alzheimer's disease (AD), which provides a prototype for developing new drugs suitable for AD therapy (197). EHT1864 can reduce kidney injury caused by salt and aldosterone by abnormal activation of the mineralocorticoid receptor (MR) mediated by Rac1 (198). Ziegler, et al. also confirmed that the use of EHT1864 can promote DNA repair and reduce DNA damage induced by radiotherapy (IR) (199). Rac1 inhibitors are considered to be beneficial in the treatment of many diseases, but at the same time, some scholars have proposed that the widespread use of Racl inhibitors (such as NSC23766 and EHT1864) may cause serious off-target effects in mouse platelets (200). It is interesting to note that Xie, et al. found that deacetylepoxydiene (DA-MED) acts as a Racl agonist in human NSCLC H1299 cells with p53 gene deletion and also activates the massive production of ROS (201).

It is worth noting that Racl inhibitors have made some breakthroughs in the clinical applications. R- ketorolac, as a component of a racemic drug approved by the FDA to relieve pain, is a dual Rac1/Cdc42 inhibitor, which can reduce the invasive biological behavior of ovarian cancer and glioblastoma (202-204). A novel anthraquinone-quinazoline hybrid 7B blocks TNBC cell migration, invasion and EMT via targeting EGFR and Rac1 (205). However, the limitations of the clinical application of Rac1 inhibitors cannot be ignored. Although NSC23766 has a good effect in the treatment of resistance to EGF-TKI in NSCLC patients, it cannot be widely used in clinical treatment due to its excessively high IC50 (50 Um) (206). With the discovery of new functions of Rac1 in other diseases, the treatment targeting Racl is undoubtedly a promising treatment option. Therefore, there is an urgent need to develop more new Rac1 inhibitors which can be widely used in clinical treatment (Figure 5).

\section{CONCLUSION}

Rac1, as a cytoskeletal regulator, regulates the polymerization of actin and promotes the migration and invasion of tumor cells, thus playing a key role in tumor evolution. Racl is highly expressed in different types of tumors, and it is related to poor prognosis. In addition, Racl is not only involved in tumor cell 


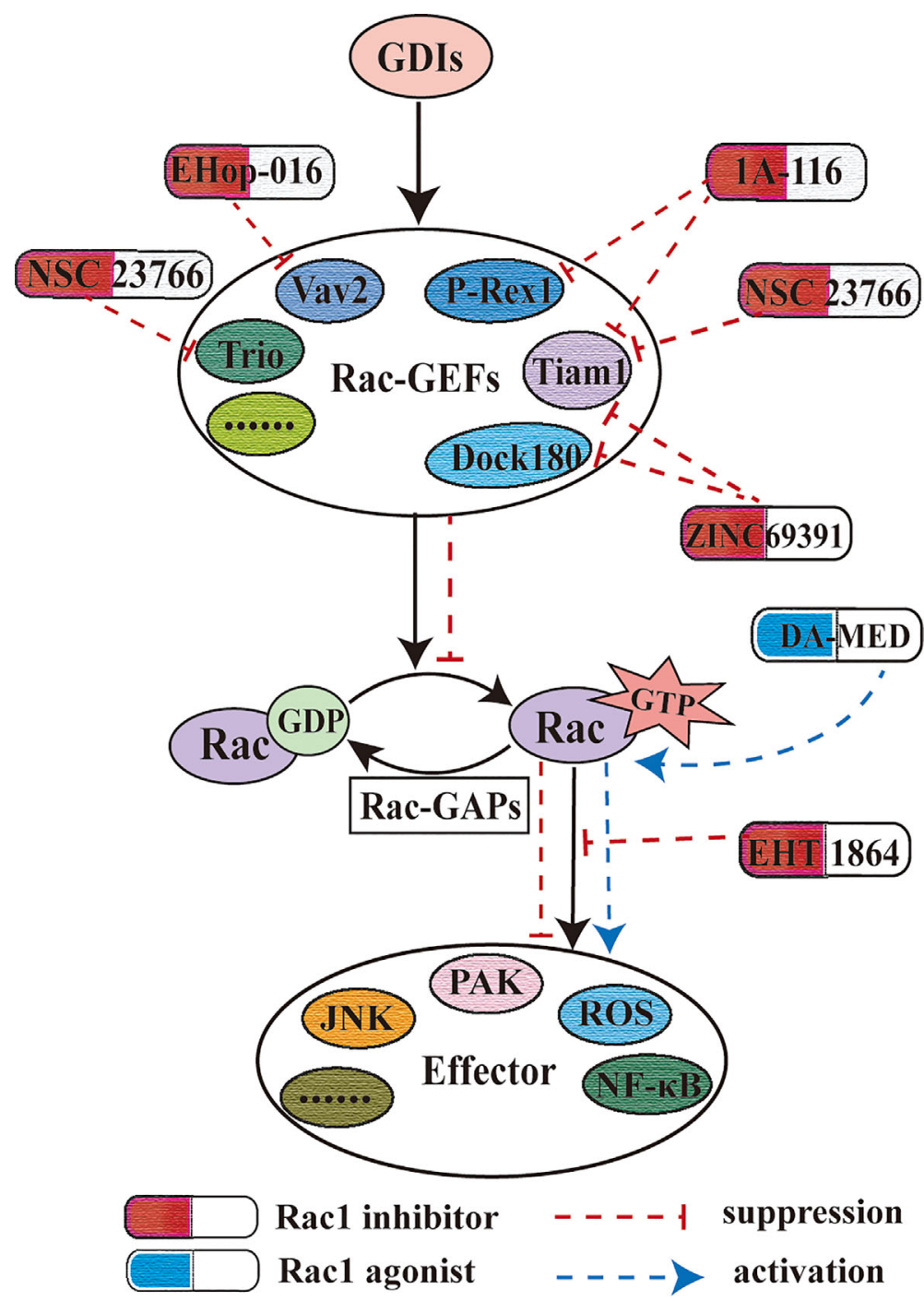

FIGURE 5 | Rac1 inhibitor and Rac1 agonist. Rac1 inhibitors play a role by blocking the activation of Rac1 by guanine nucleotide factor, the upstream effector of Rac1. This figure also shows the effect of the different Rac1 inhibitors mentioned herein on Rac1-GEF.

cycle, apoptosis, proliferation, invasion, migration, and angiogenesis, but also involved in the regulation of tumor cell stemness, thus promoting the occurrence of tumors. In addition, Racl, as an entry point to explain the mechanism of drug resistance, also plays a key role in anti-tumor therapy and participates in immune escape mediated by the tumor microenvironment. Racl inhibitors have good prospects in the prevention and treatment of tumors. Therefore, Rac1 is considered a potential target for the prevention and treatment of cancers.

\section{AUTHOR CONTRIBUTIONS}

JXL and LO contributed to drafting and editing the manuscript, shared the first authorship. QL and YZ designed, revised, and finalized the manuscript. SR, YH, XL, and PY participated in the drafting and editing manuscript. JGL, LX, and JH participated in the revision and coordination. ST, LT, and QP contributed to the literature search. YT participated in the conception and coordination. All authors contributed toward data analysis, drafting, and revising the paper and agreed to be accountable for all aspects of the work. All authors contributed to the article and approved the submitted version.

\section{FUNDING}

This work was supported in part by grants from the following sources: the National Natural Science Foundation of China (81972636, 81872281, 81772842), the Natural Science Foundation of Hunan Province (2020JJ5336, 2019JJ40175, 
2019JJ40183 2018JJ1013), the Research Project of Health Commission of Hunan Province (202109031837, 20201020), China Hunan Provincial Science and Technology Department (2018SK7005), Ascend Foundation of National cancer center
(NCC2018b68), and Supported By Hunan Cancer Hospital Climb Plan (ZX2020001-3, YF2020002) and By the Fundamental Research Funds for the Central Universities of Central South University (2019zzts832, 2019zzts833).

\section{REFERENCES}

1. Van Aelst L, D'Souza-Schorey C. Rho Gtpases and Signaling Networks. Genes Dev (1997) 11(18):2295-322. doi: 10.1101/gad.11.18.2295

2. Hall A. Rho Gtpases and the Actin Cytoskeleton. Science (1998) 279 (5350):509-14. doi: 10.1126/science.279.5350.509

3. Benitah SA, Valeron PF, van Aelst L, Marshall CJ, Lacal JC. Rho Gtpases in Human Cancer: An Unresolved Link to Upstream and Downstream Transcriptional Regulation. Biochim Biophys Acta (2004) 1705(2):121-32. doi: 10.1016/j.bbcan.2004.10.002

4. Bosco EE, Mulloy JC, Zheng Y. Racl Gtpase: A "Rac" of All Trades. Cell Mol Life Sci (2009) 66(3):370-4. doi: 10.1007/s00018-008-8552-x

5. Recouvreux MV, Commisso C. Macropinocytosis: A Metabolic Adaptation to Nutrient Stress in Cancer. Front Endocrinol (Lausanne) (2017) 8:261. doi: 10.3389/fendo.2017.00261

6. Nouri K, Timson DJ, Ahmadian MR. New Model for the Interaction of IQGAP1 With CDC42 and RAC1. Small GTPases (2020) 11(1):16-22. doi: 10.1080/21541248.2017.1321169

7. Cherfils J, Zeghouf M. Regulation of Small Gtpases by Gefs, Gaps, and Gdis. Physiol Rev (2013) 93(1):269-309. doi: 10.1152/physrev.00003.2012

8. Etienne-Manneville S, Hall A. Rho Gtpases in Cell Biology. Nature (2002) 420(6916):629-35. doi: 10.1038/nature01148

9. Tebar F, Enrich C, Rentero C, Grewal T. Gtpases Racl and Ras Signaling From Endosomes. Prog Mol Subcell Biol (2018) 57:65-105. doi: 10.1007/9783-319-96704-2_3

10. Bustelo XR, Sauzeau V, Berenjeno IM. GTP-Binding Proteins of the Rho/Rac Family: Regulation, Effectors and Functions in Vivo. Bioessays (2007) 29 (4):356-70. doi: 10.1002/bies.20558

11. Lauer JC, Selig M, Hart ML, Kurz B, Rolauffs B. Articular Chondrocyte Phenotype Regulation Through the Cytoskeleton and the Signaling Processes That Originate From or Converge on the Cytoskeleton: Towards a Novel Understanding of the Intersection Between Actin Dynamics and Chondrogenic Function. Int J Mol Sci (2021) 22(6). doi: 10.3390/ijms22063279

12. Cardama GA, Alonso DF, Gonzalez N, Maggio J, Gomez DE, Rolfo C, et al. Relevance of Small Gtpase Rac1 Pathway in Drug and Radio-Resistance Mechanisms: Opportunities in Cancer Therapeutics. Crit Rev Oncol Hematol (2018) 124:29-36. doi: 10.1016/j.critrevonc.2018.01.012

13. Ridley AJ, Paterson HF, Johnston CL, Diekmann D, Hall A. The Small GTPBinding Protein Rac Regulates Growth Factor-Induced Membrane Ruffling. Cell (1992) 70(3):401-10. doi: 10.1016/0092-8674(92)90164-8

14. Ridley AJ, Comoglio PM, Hall A. Regulation of Scatter Factor/Hepatocyte Growth Factor Responses by Ras, Rac, and Rho in MDCK Cells. Mol Cell Biol (1995) 15(2):1110-22. doi: 10.1128/mcb.15.2.1110

15. Norman JC, Price LS, Ridley AJ, Koffer A. The Small GTP-Binding Proteins, Rac and Rho, Regulate Cytoskeletal Organization and Exocytosis in Mast Cells by Parallel Pathways. Mol Biol Cell (1996) 7(9):1429-42. doi: 10.1091/mbc.7.9.1429

16. Suidan HS, Nobes CD, Hall A, Monard D. Astrocyte Spreading in Response to Thrombin and Lysophosphatidic Acid is Dependent on the Rho Gtpase. Glia (1997) 21(2):244-52. doi: 10.1002/(sici)1098-1136(199710)21:2<244:: aid-glia7>3.0.co;2-6

17. Pestonjamasp KN, Forster C, Sun C, Gardiner EM, Bohl B, Weiner O, et al. Racl Links Leading Edge and Uropod Events Through Rho and Myosin Activation During Chemotaxis. Blood (2006) 108(8):2814-20. doi: 10.1182/ blood-2006-01-010363

18. Liu Y, Dou Y, Yan L, Yang X, He B, Kong L, et al. The Role of Rho Gtpases' Substrates Rac and Cdc42 in Osteoclastogenesis and Relevant Natural Medicinal Products Study. Biosci Rep (2020) 40(7). doi: 10.1042/BSR20200407

19. Mierke CT, Puder S, Aermes C, Fischer T, Kunschmann T. Effect of PAK Inhibition on Cell Mechanics Depends on Rac1. Front Cell Dev Biol (2020) 8:13. doi: $10.3389 /$ fcell.2020.00013
20. Lopez-Guerrero AM, Espinosa-Bermejo N, Sanchez-Lopez I, Macartney T, Pascual-Caro C, Orantos-Aguilera Y, et al. RAC1-Dependent ORAI1 Translocation to the Leading Edge Supports Lamellipodia Formation and Directional Persistence. Sci Rep (2020) 10(1):6580. doi: 10.1038/s41598-02063353-5

21. Ridley AJ, Allen WE, Peppelenbosch M, Jones GE. Rho Family Proteins and Cell Migration. Biochem Soc Symp (1999) 65:111-23.

22. Leyden F, Uthishtran S, Moorthi UK, York HM, Patil A, Gandhi H, et al. Racl Activation Can Generate Untemplated, Lamellar Membrane Ruffles. BMC Biol (2021) 19(1):72. doi: 10.1186/s12915-021-00997-3

23. Becsky D, Gyulai-Nagy S, Balind A, Horvath P, Dux L, Keller-Pinter A. Myoblast Migration and Directional Persistence Affected by Syndecan-4Mediated Tiam-1 Expression and Distribution. Int J Mol Sci (2020) 21 (3):823. doi: 10.3390/ijms21030823

24. Zmurchok C, Holmes WR. Simple Rho Gtpase Dynamics Generate a Complex Regulatory Landscape Associated With Cell Shape. Biophys J (2020) 118(6):1438-54. doi: 10.1016/j.bpj.2020.01.035

25. Yuki KE, Marei H, Fiskin E, Eva MM, Gopal AA, Schwartzentruber JA, et al CYRI/FAM49B Negatively Regulates RAC1-Driven Cytoskeletal Remodelling and Protects Against Bacterial Infection. Nat Microbiol (2019) 4(9):1516-31. doi: 10.1038/s41564-019-0484-8

26. Kozma R, Sarner S, Ahmed S, Lim L. Rho Family Gtpases and Neuronal Growth Cone Remodelling: Relationship Between Increased Complexity Induced by $\mathrm{Cdc} 42 \mathrm{Hs}$, Rac1, and Acetylcholine and Collapse Induced by Rhoa and Lysophosphatidic Acid. Mol Cell Biol (1997) 17(3):1201-11. doi: $10.1128 / \mathrm{mcb} \cdot 17.3 .1201$

27. Yamazaki S, Su Y, Maruyama A, Makinoshima H, Suzuki J, Tsuboi M, et al Uptake of Collagen Type I Via Macropinocytosis Cause Mtor Activation and Anti-Cancer Drug Resistance. Biochem Biophys Res Commun (2020) 526 (1):191-8. doi: 10.1016/j.bbrc.2020.03.067

28. Krauthammer M, Kong Y, Ha BH, Evans P, Bacchiocchi A, McCusker JP, et al. Exome Sequencing Identifies Recurrent Somatic RAC1 Mutations in Melanoma. Nat Genet (2012) 44(9):1006-14. doi: 10.1038/ng.2359

29. Mohan AS, Dean KM, Isogai T, Kasitinon SY, Murali VS, Roudot P, et al Enhanced Dendritic Actin Network Formation in Extended Lamellipodia Drives Proliferation in Growth-Challenged Rac1(P29S) Melanoma Cells. Dev Cell (2019) 49(3):444-60.e9. doi: 10.1016/j.devcel.2019.04.007

30. Crawford M, Leclerc V, Barr K, Dagnino L. Essential Role for IntegrinLinked Kinase in Melanoblast Colonization of the Skin. J Invest Dermatol (2020) 140(2):425-34.e10. doi: 10.1016/j.jid.2019.07.681

31. Alauddin M, Okumura T, Rajaxavier J, Khozooei S, Poschel S, Takeda S, et al. Gut Bacterial Metabolite Urolithin a Decreases Actin Polymerization and Migration in Cancer Cells. Mol Nutr Food Res (2020) 64(7):e1900390. doi: $10.1002 / \mathrm{mnfr} .201900390$

32. Acuner SE, Sumbul F, Torun H, Haliloglu T. Oncogenic Mutations on Rac1 Affect Global Intrinsic Dynamics Underlying GTP and PAK1 Binding. Biophys J (2021) 120(5):866-76. doi: 10.1016/j.bpj.2021.01.016

33. Shao YG, Ning K, Li F. Group II P21-Activated Kinases as Therapeutic Targets in Gastrointestinal Cancer. World J Gastroenterol (2016) 22 (3):1224-35. doi: 10.3748/wjg.v22.i3.1224

34. Joseph GA, Lu M, Radu M, Lee JK, Burden SJ, Chernoff J, et al. Group I Paks Promote Skeletal Myoblast Differentiation in Vivo and in Vitro. Mol Cell Biol (2017) 37(4). doi: 10.1128/MCB.00222-16

35. Bagrodia S, Cerione RA. Pak to the Future. Trends Cell Biol (1999) 9(9):3505. doi: 10.1016/s0962-8924(99)01618-9

36. Klopocka W, Korczynski J, Pomorski P. Cytoskeleton and Nucleotide Signaling in Glioma C6 Cells. Adv Exp Med Biol (2020) 1202:109-28. doi: 10.1007/978-3-030-30651-9_6

37. Fan G, Zhang S, Gao Y, Greer PA, Tonks NK. HGF-Independent Regulation of MET and GAB1 by Nonreceptor Tyrosine Kinase FER Potentiates 
Metastasis in Ovarian Cancer. Genes Dev (2016) 30(13):1542-57. doi: $10.1101 /$ gad.284166.116

38. Fan G. FER Mediated HGF-Independent Regulation of HGFR/MET Activates RAC1-PAK1 Pathway to Potentiate Metastasis in Ovarian Cancer. Small GTPases (2020) 11(3):155-9. doi: 10.1080/21541248. 2017.1379931

39. Islam SMA, Patel R, Acevedo-Duncan M. Protein Kinase C-Zeta Stimulates Colorectal Cancer Cell Carcinogenesis Via PKC-Zeta/Rac1/Pak1/BetaCatenin Signaling Cascade. Biochim Biophys Acta Mol Cell Res (2018) 1865(4):650-64. doi: 10.1016/j.bbamcr.2018.02.002

40. Leng R, Liao G, Wang H, Kuang J, Tang L. Racl Expression in Epithelial Ovarian Cancer: Effect on Cell EMT and Clinical Outcome. Med Oncol (2015) 32(2):329. doi: 10.1007/s12032-014-0329-5

41. Lin Y, Fu F, Lv J, Wang M, Li Y, Zhang J, et al. Identification of Potential Key Genes for HER-2 Positive Breast Cancer Based on Bioinformatics Analysis. Med (Baltimore) (2020) 99(1):e18445. doi: 10.1097/MD.0000000000018445

42. Wang P, Liu GZ, Wang JF, Du YY. SNHG3 Silencing Suppresses the Malignant Development of Triple-Negative Breast Cancer Cells by Regulating Mirna-326/Integrin Alpha5 Axis and Inactivating Vav2/Rac1 Signaling Pathway. Eur Rev Med Pharmacol Sci (2020) 24(10):5481-92. doi: 10.26355/eurrev_202005_21333

43. Xia L, Lin J, Su J, Oyang L, Wang H, Tan S, et al. Diallyl Disulfide Inhibits Colon Cancer Metastasis by Suppressing Rac1-Mediated EpithelialMesenchymal Transition. Onco Targets Ther (2019) 12:5713-28. doi: 10.2147/OTT.S208738

44. Wu Y, Zhao Y, Huan L, Zhao J, Zhou Y, Xu L, et al. An LTR Retrotransposon-Derived Long Noncoding RNA Lncmer52a Promotes Hepatocellular Carcinoma Progression by Binding P120-Catenin. Cancer Res (2020) 80(5):976-87. doi: 10.1158/0008-5472.CAN-19-2115

45. Lopez-Cortes A, Paz YMC, Guerrero S, Cabrera-Andrade A, Barigye SJ, Munteanu CR, et al. Oncoomics Approaches to Reveal Essential Genes in Breast Cancer: A Panoramic View From Pathogenesis to Precision Medicine. Sci Rep (2020) 10(1):5285. doi: 10.1038/s41598-020-62279-2

46. Venugopal SV, Caggia S, Gambrell-Sanders D, Khan SA. Differential Roles and Activation of Mammalian Target of Rapamycin Complexes 1 and 2 During Cell Migration in Prostate Cancer Cells. Prostate (2020) 80(5):41223. doi: $10.1002 /$ pros. 23956

47. Chang F, Lemmon C, Lietha D, Eck M, Romer L. Tyrosine Phosphorylation of Racl: A Role in Regulation of Cell Spreading. PloS One (2011) 6(12): e28587. doi: 10.1371/journal.pone.0028587

48. Kwon T, Kwon DY, Chun J, Kim JH, Kang SS. Akt Protein Kinase Inhibits Rac1-GTP Binding Through Phosphorylation At Serine 71 of Rac1. J Biol Chem (2000) 275(1):423-8. doi: 10.1074/jbc.275.1.423

49. Castillo-Lluva S, Tan CT, Daugaard M, Sorensen PH, Malliri A. The Tumour Suppressor HACE1 Controls Cell Migration by Regulating Rac1 Degradation. Oncogene (2013) 32(13):1735-42. doi: 10.1038/onc.2012.189

50. Zhao J, Mialki RK, Wei J, Coon TA, Zou C, Chen BB, et al. SCF E3 Ligase FBox Protein Complex SCF(FBXL19) Regulates Cell Migration by Mediating Rac1 Ubiquitination and Degradation. FASEB J (2013) 27(7):2611-9. doi: $10.1096 / f j .12-223099$

51. Worby CA, Mattoo S, Kruger RP, Corbeil LB, Koller A, Mendez JC, et al. The Fic Domain: Regulation of Cell Signaling by Adenylylation. Mol Cell (2009) 34(1):93-103. doi: 10.1016/j.molcel.2009.03.008

52. Abdrabou A, Wang Z. Post-Translational Modification and Subcellular Distribution of Racl: An Update. Cells (2018) 7(12):263. doi: 10.3390/ cells7120263

53. Olson MF. Rho Gtpases, Their Post-Translational Modifications, DiseaseAssociated Mutations and Pharmacological Inhibitors. Small GTPases (2018) 9(3):203-15. doi: 10.1080/21541248.2016.1218407

54. Kawazu M, Ueno T, Kontani K, Ogita Y, Ando M, Fukumura K, et al. Transforming Mutations of RAC Guanosine Triphosphatases in Human Cancers. Proc Natl Acad Sci USA (2013) 110(8):3029-34. doi: 10.1073/ pnas. 1216141110

55. Bright MD, Clarke PA, Workman P, Davies FE. Oncogenic RAC1 and NRAS Drive Resistance to Endoplasmic Reticulum Stress Through MEK/ERK Signalling. Cell Signal (2018) 44:127-37. doi: 10.1016/j.cellsig.2018.01.004

56. Toyama Y, Kontani K, Katada T, Shimada I. Conformational Landscape Alternations Promote Oncogenic Activities of Ras-Related C3 Botulinum
Toxin Substrate 1 as Revealed by NMR. Sci Adv (2019) 5(3):eaav8945. doi: 10.1126/sciadv.aav8945

57. Chang MT, Asthana S, Gao SP, Lee BH, Chapman JS, Kandoth C, et al. Identifying Recurrent Mutations in Cancer Reveals Widespread Lineage Diversity and Mutational Specificity. Nat Biotechnol (2016) 34(2):155-63. doi: $10.1038 /$ nbt. 3391

58. Senyuz S, Jang H, Nussinov R, Keskin O, Gursoy A. Mechanistic Differences of Activation of Rac1(P29S) and Racl(A159V). J Phys Chem B (2021) 125 (15):3790-802. doi: 10.1021/acs.jpcb.1c00883

59. Kamai T, Shirataki H, Nakanishi K, Furuya N, Kambara T, Abe H, et al. Increased Racl Activity and Pakl Overexpression are Associated With Lymphovascular Invasion and Lymph Node Metastasis of Upper Urinary Tract Cancer. BMC Cancer (2010) 10:164. doi: 10.1186/1471-2407-10-164

60. Zhou Y, Liao Q, Han Y, Chen J, Liu Z, Ling H, et al. Rac1 Overexpression is Correlated With Epithelial Mesenchymal Transition and Predicts Poor Prognosis in Non-Small Cell Lung Cancer. J Cancer (2016) 7(14):2100-9. doi: 10.7150/jca.16198

61. Shan G, Tang T, Qian H, Xia Y. Expression of Tiam1 and Rac1 Proteins in Renal Cell Carcinoma and Its Clinical-Pathological Features. Int J Clin Exp Pathol (2017) 10(11):11114-21.

62. Wu YJ, Tang Y, Li ZF, Li Z, Zhao Y, Wu ZJ, et al. Expression and Significance of Rac1, Pak1 and Rock1 in Gastric Carcinoma. Asia Pac J Clin Oncol (2014) 10(2):e33-9. doi: 10.1111/ajco.12052

63. Du X, Wang S, Lu J, Wang Q, Song N, Yang T, et al. Clinical Value of Tiam1Rac1 Signaling in Primary Gallbladder Carcinoma. Med Oncol (2012) 29 (3):1873-8. doi: 10.1007/s12032-011-0046-2

64. Yang W, Lv S, Liu X, Liu H, Yang W, Hu F. Up-Regulation of Tiam1 and Racl Correlates With Poor Prognosis in Hepatocellular Carcinoma. Jpn J Clin Oncol (2010) 40(11):1053-9. doi: 10.1093/jjco/hyq086

65. Zhang J, Wang C, Yan S, Yang Y, Zhang X, Guo W. Mir-345 Inhibits Migration and Stem-Like Cell Phenotype in Gastric Cancer Via Inactivation of Rac1 by Targeting EPS8. Acta Biochim Biophys Sin (Shanghai) (2020) 52 (3):259-67. doi: 10.1093/abbs/gmz166

66. Goka ET, Mesa Lopez DT, Lippman ME. Hormone Dependent Prostate Cancers are Dependent on Rac Signaling for Growth and Survival. Mol Cancer Ther (2021). doi: 10.1158/1535-7163.MCT-20-0695

67. Kogler M, Tortola L, Negri GL, Leopoldi A, El-Naggar AM, Mereiter S, et al. HACE1 Prevents Lung Carcinogenesis Via Inhibition of RAC-Family Gtpases. Cancer Res (2020) 80(14):3009-22. doi: 10.1158/0008-5472.CAN-19-2270

68. Lou S, Wang P, Yang J, Ma J, Liu C, Zhou M. Prognostic and Clinicopathological Value of Rac1 in Cancer Survival: Evidence From a Meta-Analysis. J Cancer (2018) 9(14):2571-9. doi: 10.7150/jca.24824

69. Merajver SD, Usmani SZ. Multifaceted Role of Rho Proteins in Angiogenesis. J Mammary Gland Biol Neoplasia (2005) 10(4):291-8. doi: 10.1007/s10911-006-9002-8

70. Wang FS, Wang CJ, Chen YJ, Chang PR, Huang YT, Sun YC, et al. Ras Induction of Superoxide Activates ERK-Dependent Angiogenic Transcription Factor HIF-1alpha and VEGF-a Expression in Shock WaveStimulated Osteoblasts. J Biol Chem (2004) 279(11):10331-7. doi: 10.1074/ jbc.M308013200

71. Michaelson D, Abidi W, Guardavaccaro D, Zhou M, Ahearn I, Pagano M, et al. Rac1 Accumulates in the Nucleus During the G2 Phase of the Cell Cycle and Promotes Cell Division. J Cell Biol (2008) 181(3):485-96. doi: $10.1083 /$ jcb. 200801047

72. Lamarche N, Tapon N, Stowers L, Burbelo PD, Aspenstrom P, Bridges T, et al. Rac and Cdc42 Induce Actin Polymerization and G1 Cell Cycle Progression Independently of P65pak and the JNK/SAPK MAP Kinase Cascade. Cell (1996) 87(3):519-29. doi: 10.1016/s0092-8674(00)81371-9

73. Chou MM, Blenis J. The 70 Kda S6 Kinase Complexes With and is Activated by the Rho Family G Proteins Cdc42 and Rac1. Cell (1996) 85(4):573-83. doi: 10.1016/s0092-8674(00)81257-x

74. Wang L, Shen S, Xiao H, Ding F, Wang M, Li G, et al. ARHGAP24 Inhibits Cell Proliferation and Cell Cycle Progression and Induces Apoptosis of Lung Cancer Via a STAT6-WWP2-P27 Axis. Carcinogenesis (2019) 41(5):711-21. doi: 10.1093/carcin/bgz144

75. Wan J, Cao Y, Abdelaziz MH, Huang L, Kesavan DK, Su Z, et al. Downregulated Rac1 Promotes Apoptosis and Inhibits the Clearance of Apoptotic Cells in Airway Epithelial Cells, Which May Be Associated With 
Airway Hyper-Responsiveness in Asthma. Scand J Immunol (2019) 89(5): e12752. doi: $10.1111 /$ sji.12752

76. Gerasimcik N, He M, Dahlberg CIM, Kuznetsov NV, Severinson E, Westerberg LS. The Small Rho Gtpases Rac1 and Rac2 are Important for T-Cell Independent Antigen Responses and for Suppressing Switching to Igg2b in Mice. Front Immunol (2017) 8:1264. doi: 10.3389/fimmu. 2017.01264

77. Velaithan R, Kang J, Hirpara JL, Loh T, Goh BC, Le Bras M, et al. The Small Gtpase Rac1 is a Novel Binding Partner of Bcl-2 and Stabilizes Its Antiapoptotic Activity. Blood (2011) 117(23):6214-26. doi: 10.1182/blood2010-08-301283

78. Wu N, Ren D, Li S, Ma W, Hu S, Jin Y, et al. RCC2 Over-Expression in Tumor Cells Alters Apoptosis and Drug Sensitivity by Regulating Racl Activation. BMC Cancer (2018) 18(1):67. doi: 10.1186/s12885-017-3908-y

79. Zhang L, Zhou H, Wei G. Mir-506 Regulates Cell Proliferation and Apoptosis by Affecting Rhoa/ROCK Signaling Pathway in Hepatocellular Carcinoma Cells. Int J Clin Exp Pathol (2019) 12(4):1163-73.

80. Senger DL, Tudan C, Guiot MC, Mazzoni IE, Molenkamp G, LeBlanc R, et al. Suppression of Rac Activity Induces Apoptosis of Human Glioma Cells But Not Normal Human Astrocytes. Cancer Res (2002) 62(7):2131-40.

81. Lionarons DA, Hancock DC, Rana S, East P, Moore C, Murillo MM, et al. RAC1(P29S) Induces a Mesenchymal Phenotypic Switch Via Serum Response Factor to Promote Melanoma Development and Therapy Resistance. Cancer Cell (2019) 36(1):68-83.e9. doi: 10.1016/j.ccell. 2019.05.015

82. Li Y, Xiao F, Li W, Hu P, Xu R, Li J, et al. Overexpression of Opa Interacting Protein 5 Increases the Progression of Liver Cancer Via BMPR2/JUN/ CHEK1/RAC1 Dysregulation. Oncol Rep (2019) 41(4):2075-88. doi: 10.3892/or.2019.7006

83. Sen CK, Khanna S, Babior BM, Hunt TK, Ellison EC, Roy S. OxidantInduced Vascular Endothelial Growth Factor Expression in Human Keratinocytes and Cutaneous Wound Healing. J Biol Chem (2002) 277 (36):33284-90. doi: 10.1074/jbc.M203391200

84. Farzaneh Behelgardi M, Zahri S, Gholami Shahvir Z, Mashayekhi F, Mirzanejad L, Asghari SM. Targeting Signaling Pathways of VEGFR1 and VEGFR2 as a Potential Target in the Treatment of Breast Cancer. Mol Biol Rep (2020) 47(3):2061-71. doi: 10.1007/s11033-020-05306-9

85. Laddha AP, Kulkarni YA. NADPH Oxidase: A Membrane-Bound Enzyme and Its Inhibitors in Diabetic Complications. Eur J Pharmacol (2020) 881:173206. doi: 10.1016/j.ejphar.2020.173206

86. Zhang XZ, Huang X, Qiao JH, Zhang JJ, Zhang MX. Inhibition of HypoxiaInduced Retinal Neovascularization in Mice With Short Hairpin RNA Targeting Rac1, Possibly Via Blockading Redox Signaling. Exp Eye Res (2011) 92(6):473-81. doi: 10.1016/j.exer.2011.03.005

87. Wang H, Ramshekar A, Kunz E, Sacks DB, Hartnett ME. IQGAP1 Causes Choroidal Neovascularization by Sustaining VEGFR2-Mediated Rac1 Activation. Angiogenesis (2020) 23(4):685-98. doi: 10.1007/s10456-020-09740-y

88. Balaji Ragunathrao VA, Anwar M, Akhter MZ, Chavez A, Mao Y, Natarajan V, et al. Sphingosine-1-Phosphate Receptor 1 Activity Promotes Tumor Growth by Amplifying VEGF-VEGFR2 Angiogenic Signaling. Cell Rep (2019) 29(11):3472-87.e4. doi: 10.1016/j.celrep.2019.11.036

89. Wang X, Yao Y, Gao J. Sevoflurane Inhibits Growth Factor-Induced Angiogenesis Through Suppressing Rac1/Paxillin/FAK and Ras/Akt/Mtor. Future Oncol (2020) 16(22):1619-27. doi: 10.2217/fon-2020-0221

90. Liu S, Chen J, Shi J, Zhou W, Wang L, Fang W, et al. M1-Like MacrophageDerived Exosomes Suppress Angiogenesis and Exacerbate Cardiac Dysfunction in a Myocardial Infarction Microenvironment. Basic Res Cardiol (2020) 115(2):22. doi: 10.1007/s00395-020-0781-7

91. Bu F, Min JW, Munshi Y, Lai YJ, Qi L, Urayama A, et al. Activation of Endothelial Ras-Related C3 Botulinum Toxin Substrate 1 (Rac1) Improves Post-Stroke Recovery and Angiogenesis Via Activating Pak1 in Mice. Exp Neurol (2019) 322:113059. doi: 10.1016/j.expneurol.2019.113059

92. Xia P, Huang $M$, Zhang Y, Xiong X, Yan M, Xiong X, et al. NCK1 Promotes the Angiogenesis of Cervical Squamous Carcinoma Via Rac1/PAK1/MMP2 Signal Pathway. Gynecol Oncol (2019) 152(2):387-95. doi: 10.1016/j.ygyno. 2018.11.013

93. Guan T, Huang K, Liu Y, Hou S, Hu C, Li Y, et al. Aristolochic Acid Inhibits Slit2-Induced Migration and Tube Formation Via Inactivation of Robol/
Robo2-NCK1/NCK2 Signaling Pathway in Human Umbilical Vein Endothelial Cells. Toxicol Lett (2019) 300:51-8. doi: 10.1016/j.toxlet. 2018.10.022

94. Shi D, Qi M, Zhou L, Li X, Ni L, Li C, et al. Endothelial Mitochondrial Preprotein Translocase Tomm7-Rac1 Signaling Axis Dominates Cerebrovascular Network Homeostasis. Arterioscler Thromb Vasc Biol (2018) 38(11):2665-77. doi: 10.1161/ATVBAHA.118.311538

95. Parri M, Chiarugi P. Rac and Rho Gtpases in Cancer Cell Motility Control. Cell Commun Signal (2010) 8:23. doi: 10.1186/1478-811X-8-23

96. Yang J, Qiu Q, Qian X, Yi J, Jiao Y, Yu M, et al. Long Noncoding RNA LCAT1 Functions as a Cerna to Regulate RAC1 Function by Sponging Mir4715-5p in Lung Cancer. Mol Cancer (2019) 18(1):171. doi: 10.1186/s12943019-1107-y

97. Li WQ, Zhao WC, Xin J, Niu TL, Chao YF, Zhou P, et al. Microrna-142-3p Suppresses Cell Proliferation and Migration in Bladder Cancer Via Rac1. J Biol Regul Homeost Agents (2020) 34(1). doi: 10.23812/19-460-A

98. Pham TQ, Robinson K, Xu L, Pavlova MN, Skapek SX, Chen EY. HDAC6 Promotes Growth, Migration/Invasion, and Self-Renewal of Rhabdomyosarcoma. Oncogene (2021) 40(3):578-91. doi: 10.1038/s41388020-01550-2

99. Liu X, Wang Q, Liu B, Zheng X, Li P, Zhao T, et al. Genistein Inhibits Radiation-Induced Invasion and Migration of Glioblastoma Cells by Blocking the DNA-Pkcs/Akt2/Rac1 Signaling Pathway. Radiother Oncol (2021) 155:93-104. doi: 10.1016/j.radonc.2020.10.026

100. Smalley T, Islam SMA, Apostolatos C, Apostolatos A, Acevedo-Duncan M. Analysis of PKC-Zeta Protein Levels in Normal and Malignant Breast Tissue Subtypes. Oncol Lett (2019) 17(2):1537-46. doi: 10.3892/ol.2018.9792

101. Pasquier J, Abu-Kaoud N, Abdesselem H, Madani A, Hoarau-Vechot J, Thawadi HA, et al. SDF-1alpha Concentration Dependent Modulation of Rhoa and Rac1 Modifies Breast Cancer and Stromal Cells Interaction. BMC Cancer (2015) 15:569. doi: 10.1186/s12885-015-1556-7

102. Khan S, Shukla S, Farhan M, Sinha S, Lakra AD, Penta D, et al. Centchroman Prevents Metastatic Colonization of Breast Cancer Cells and Disrupts Angiogenesis Via Inhibition of RAC1/PAK1/Beta-Catenin Signaling Axis. Life Sci (2020) 256:117976. doi: 10.1016/j.lfs.2020.117976

103. Bauer NN, Chen YW, Samant RS, Shevde LA, Fodstad O. Racl Activity Regulates Proliferation of Aggressive Metastatic Melanoma. Exp Cell Res (2007) 313(18):3832-9. doi: 10.1016/j.yexcr.2007.08.017

104. Su J, Zhou Y, Pan Z, Shi L, Yang J, Liao A, et al. Downregulation of LIMK1$\mathrm{ADF} / \mathrm{Cofilin}$ by DADS Inhibits the Migration and Invasion of Colon Cancer. Sci Rep (2017) 7:45624. doi: 10.1038/srep45624

105. Zhou Y, Su J, Shi L, Liao Q, Su Q. DADS Downregulates the Rac1-ROCK1/ PAK1-LIMK1-ADF/Cofilin Signaling Pathway, Inhibiting Cell Migration and Invasion. Oncol Rep (2013) 29(2):605-12. doi: 10.3892/or.2012.2168

106. Zhang T, Wang Z, Liu Y, Huo Y, Liu H, Xu C, et al. Plastin 1 Drives Metastasis of Colorectal Cancer Through the IQGAP1/Rac1/ERK Pathway. Cancer Sci (2020) 111(8):2861-71. doi: 10.1111/cas.14438

107. Hoefle C, McCollum C, Huckelhoven R. Barley ROP-Interactive Partner-a Organizes Into RAC1- and MICROTUBULE-ASSOCIATED ROP-GTPASE ACTIVATING PROTEIN 1-Dependent Membrane Domains. BMC Plant Biol (2020) 20(1):94. doi: 10.1186/s12870-020-2299-4

108. Gonzalez DM, Medici D. Signaling Mechanisms of the EpithelialMesenchymal Transition. Sci Signal (2014) 7(344):re8. doi: 10.1126/ scisignal.2005189

109. Zhang L, Zhang B, You W, Li P, Kuang Y. Rab23 Promotes Hepatocellular Carcinoma Cell Migration Via Rac1/TGF-Beta Signaling. Pathol Oncol Res (2020) 26(1):301-6. doi: 10.1007/s12253-018-0463-Z

110. Xu Q, Chen J, Peng M, Duan S, Hu Y, Guo D, et al. POTEE Promotes Colorectal Carcinoma Progression Via Activating the Rac1/Cdc42 Pathway. Exp Cell Res (2020) 390(1):111933. doi: 10.1016/j.yexcr.2020.111933

111. Li X, Zhu J, Liu Y, Duan C, Chang R, Zhang C. Microrna-331-3p Inhibits Epithelial-Mesenchymal Transition by Targeting Erbb2 and VAV2 Through the Rac1/PAK1/Beta-Catenin Axis in Non-Small-Cell Lung Cancer. Cancer Sci (2019) 110(6):1883-96. doi: 10.1111/cas.14014

112. Al-Koshab M, Alabsi AM, Bakri MM, Naicker MS, Seyedan A. Chemopreventive Activity of Tualang Honey Against Oral Squamous Cell Carcinoma-in Vivo. Oral Surg Oral Med Oral Pathol Oral Radiol (2020) 129 (5):484-92. doi: 10.1016/j.0ooo.2020.01.009 
113. Liu C, Zhang L, Cui W, Du J, Li Z, Pang Y, et al. Epigenetically Upregulated GEFT-Derived Invasion and Metastasis of Rhabdomyosarcoma Via Epithelial Mesenchymal Transition Promoted by the Rac1/Cdc42-PAK Signalling Pathway. EBioMedicine (2019) 50:122-34. doi: 10.1016/ j.ebiom.2019.10.060

114. Xu T, He BS, Pan B, Pan YQ, Sun HL, Liu XX, et al. Mir-142-3p Functions as a Tumor Suppressor by Targeting RAC1/PAK1 Pathway in Breast Cancer. J Cell Physiol (2020) 235(5):4928-40. doi: 10.1002/jcp.29372

115. Rao J, Zhou ZH, Yang J, Shi Y, Xu SL, Wang B, et al. Semaphorin-3F Suppresses the Stemness of Colorectal Cancer Cells by Inactivating Rac1. Cancer Lett (2015) 358(1):76-84. doi: 10.1016/j.canlet.2014.12.040

116. Myant KB, Scopelliti A, Haque S, Vidal M, Sansom OJ, Cordero JB. Rac1 Drives Intestinal Stem Cell Proliferation and Regeneration. Cell Cycle (2013) 12(18):2973-7. doi: 10.4161/cc.26031

117. Myant KB, Cammareri P, McGhee EJ, Ridgway RA, Huels DJ, Cordero JB, et al. ROS Production and NF-Kappab Activation Triggered by RAC1 Facilitate WNT-Driven Intestinal Stem Cell Proliferation and Colorectal Cancer Initiation. Cell Stem Cell (2013) 12(6):761-73. doi: 10.1016/ j.stem.2013.04.006

118. Olabi S, Ucar A, Brennan K, Streuli CH. Integrin-Rac Signalling for Mammary Epithelial Stem Cell Self-Renewal. Breast Cancer Res (2018) 20 (1):128. doi: 10.1186/s13058-018-1048-1

119. Xiao Y, Li Y, Tao H, Humphries B, Li A, Jiang Y, et al. Integrin Alpha5 Down-Regulation by Mir-205 Suppresses Triple Negative Breast Cancer Stemness and Metastasis by Inhibiting the Src/Vav2/Rac1 Pathway. Cancer Lett (2018) 433:199-209. doi: 10.1016/j.canlet.2018.06.037

120. Carmon KS, Gong X, Yi J, Wu L, Thomas A, Moore CM, et al. LGR5 Receptor Promotes Cell-Cell Adhesion in Stem Cells and Colon Cancer Cells Via the IQGAP1-Rac1 Pathway. J Biol Chem (2017) 292(36):14989-5001. doi: 10.1074/jbc.M117.786798

121. Chen L, Zhang D, Ding T, Liu F, Xu X, Tian Y, et al. Lncrna NR2F2-AS1 Upregulates Rac1 to Increase Cancer Stemness in Clear Cell Renal Cell Carcinoma. Cancer Biother Radiopharm (2020) 35(4):301-6. doi: 10.1089/ cbr.2019.3319

122. Elaimy AL, Guru S, Chang C, Ou J, Amante JJ, Zhu LJ, et al. VEGFNeuropilin-2 Signaling Promotes Stem-Like Traits in Breast Cancer Cells by TAZ-Mediated Repression of the Rac GAP Beta2-Chimaerin. Sci Signal (2018) 11(528). doi: 10.1126/scisignal.aao6897

123. Yoon CH, Hyun KH, Kim RK, Lee H, Lim EJ, Chung HY, et al. The Small Gtpase Rac1 is Involved in the Maintenance of Stemness and Malignancies in Glioma Stem-Like Cells. FEBS Lett (2011) 585(14):2331-8. doi: 10.1016/ j.febslet.2011.05.070

124. Man J, Shoemake J, Zhou W, Fang X, Wu Q, Rizzo A, et al. Sema3C Promotes the Survival and Tumorigenicity of Glioma Stem Cells Through Rac1 Activation. Cell Rep (2014) 9(5):1812-26. doi: 10.1016/j.celrep. 2014.10.055

125. Akunuru S, Palumbo J, Zhai QJ, Zheng Y. Rac1 Targeting Suppresses Human Non-Small Cell Lung Adenocarcinoma Cancer Stem Cell Activity. PloS One (2011) 6(2):e16951. doi: 10.1371/journal.pone.0016951

126. Jiang ZB, Ma BQ, Liu SG, Li J, Yang GM, Hou YB, et al. Mir-365 Regulates Liver Cancer Stem Cells Via RAC1 Pathway. Mol Carcinog (2019) 58(1):5565. doi: $10.1002 / \mathrm{mc} .22906$

127. Ran RZ, Chen J, Cui LJ, Lin XL, Fan MM, Cong ZZ, et al. Mir-194 Inhibits Liver Cancer Stem Cell Expansion by Regulating RAC1 Pathway. Exp Cell Res (2019) 378(1):66-75. doi: 10.1016/j.yexcr.2019.03.007

128. Mani SA, Guo W, Liao MJ, Eaton EN, Ayyanan A, Zhou AY, et al. The Epithelial-Mesenchymal Transition Generates Cells With Properties of Stem Cells. Cell (2008) 133(4):704-15. doi: 10.1016/j.cell.2008.03.027

129. Akunuru S, James Zhai Q, Zheng Y. Non-Small Cell Lung Cancer Stem/ Progenitor Cells are Enriched in Multiple Distinct Phenotypic Subpopulations and Exhibit Plasticity. Cell Death Dis (2012) 3:e352. doi: $10.1038 /$ cddis. 2012.93

130. Zhang Y, Roos M, Himburg H, Termini CM, Quarmyne M, Li M, et al. Ptpsigma Inhibitors Promote Hematopoietic Stem Cell Regeneration. Nat Commun (2019) 10(1):3667. doi: 10.1038/s41467-019-11490-5

131. Kwak EL, Ahronian LG, Siravegna G, Mussolin B, Borger DR, Godfrey JT, et al. Molecular Heterogeneity and Receptor Coamplification Drive Resistance to Targeted Therapy in MET-Amplified Esophagogastric
Cancer. Cancer Discovery (2015) 5(12):1271-81. doi: 10.1158/2159-8290. CD-15-0748

132. Dagogo-Jack I, Shaw AT. Tumour Heterogeneity and Resistance to Cancer Therapies. Nat Rev Clin Oncol (2018) 15(2):81-94. doi: 10.1038/ nrclinonc.2017.166

133. Arnold CR, Abdelmoez A, Thurner G, Debbage P, Lukas P, Skvortsov S, et al. Rac1 as a Multifunctional Therapeutic Target to Prevent and Combat Cancer Metastasis. Oncoscience (2014) 1(8):513-21. doi: 10.18632/oncoscience.74

134. Cheng C, Seen D, Zheng C, Zeng R, Li E. Role of Small Gtpase Rhoa in DNA Damage Response. Biomolecules (2021) 11(2):212. doi: 10.3390/ biom 11020212

135. Yamaguchi M, Takagi K, Sato A, Miki Y, Miyashita M, Sasano H, et al. Rac1 Activation in Human Breast Carcinoma as a Prognostic Factor Associated With Therapeutic Resistance. Breast Cancer (2020) 27(5):919-28. doi: $10.1007 / s 12282-020-01091-2$

136. Reddy BY, Miller DM, Tsao H. Somatic Driver Mutations in Melanoma. Cancer (2017) 123(S11):2104-17. doi: 10.1002/cncr.30593

137. Johnson DB, Menzies AM, Zimmer L, Eroglu Z, Ye F, Zhao S, et al. Acquired BRAF Inhibitor Resistance: A Multicenter Meta-Analysis of the Spectrum and Frequencies, Clinical Behaviour, and Phenotypic Associations of Resistance Mechanisms. Eur J Cancer (2015) 51(18):2792-9. doi: 10.1016/ j.ejca.2015.08.022

138. Olbryt M, Piglowski W, Rajczykowski M, Pfeifer A, Student S, FiszerKierzkowska A. Genetic Profiling of Advanced Melanoma: Candidate Mutations for Predicting Sensitivity and Resistance to Targeted Therapy. Target Oncol (2020) 15(1):101-13. doi: 10.1007/s11523-020-00695-0

139. Vanneste M, Feddersen CR, Varzavand A, Zhu EY, Foley T, Zhao L, et al. Functional Genomic Screening Independently Identifies CUL3 as a Mediator of Vemurafenib Resistance Via Src-Racl Signaling Axis. Front Oncol (2020) 10:442. doi: $10.3389 /$ fonc. 2020.00442

140. Watson IR, Li L, Cabeceiras PK, Mahdavi M, Gutschner T, Genovese G, et al. The RAC1 P29S Hotspot Mutation in Melanoma Confers Resistance to Pharmacological Inhibition of RAF. Cancer Res (2014) 74(17):4845-52. doi: 10.1158/0008-5472.CAN-14-1232-T

141. Li Q, Qin T, Bi Z, Hong H, Ding L, Chen J, et al. Rac1 Activates NonOxidative Pentose Phosphate Pathway to Induce Chemoresistance of Breast Cancer. Nat Commun (2020) 11(1):1456. doi: 10.1038/s41467-020-15308-7

142. Zeng RJ, Zheng CW, Gu JE, Zhang HX, Xie L, Xu LY, et al. RAC1 Inhibition Reverses Cisplatin Resistance in Esophageal Squamous Cell Carcinoma and Induces Downregulation of Glycolytic Enzymes. Mol Oncol (2019) 13 (9):2010-30. doi: 10.1002/1878-0261.12548

143. Chen QY, Xu LQ, Jiao DM, Yao QH, Wang YY, Hu HZ, et al. Silencing of Rac1 Modifies Lung Cancer Cell Migration, Invasion and Actin Cytoskeleton Rearrangements and Enhances Chemosensitivity to Antitumor Drugs. Int $J$ Mol Med (2011) 28(5):769-76. doi: 10.3892/ijmm.2011.775

144. Kaneto N, Yokoyama S, Hayakawa Y, Kato S, Sakurai H, Saiki I. RAC1 Inhibition as a Therapeutic Target for Gefitinib-Resistant Non-Small-Cell Lung Cancer. Cancer Sci (2014) 105(7):788-94. doi: 10.1111/cas.12425

145. Jin R, Wang X, Zang R, Liu C, Zheng S, Li H, et al. Desmoglein-2 Modulates Tumor Progression and Osimertinib Drug Resistance Through the EGFR/ Src/PAK1 Pathway in Lung Adenocarcinoma. Cancer Lett (2020) 483:46-58. doi: 10.1016/j.canlet.2020.04.001

146. Ikram M, Lim Y, Baek SY, Jin S, Jeong YH, Kwak JY, et al. Co-Targeting of Tiam1/Rac1 and Notch Ameliorates Chemoresistance Against Doxorubicin in a Biomimetic 3D Lymphoma Model. Oncotarget (2018) 9(2):2058-75. doi: 10.18632 /oncotarget.23156

147. Hofbauer SW, Krenn PW, Ganghammer S, Asslaber D, Pichler U, Oberascher K, et al. Tiam1/Racl Signals Contribute to the Proliferation and Chemoresistance, But Not Motility, of Chronic Lymphocytic Leukemia Cells. Blood (2014) 123(14):2181-8. doi: 10.1182/blood-2013-08-523563

148. Zhou Y, Wang Y, Zhou W, Chen T, Wu Q, Chutturghoon VK, et al. YAP Promotes Multi-Drug Resistance and Inhibits Autophagy-Related Cell Death in Hepatocellular Carcinoma Via the RAC1-ROS-Mtor Pathway. Cancer Cell Int (2019) 19:179. doi: 10.1186/s12935-019-0898-7

149. Su Z, Li Z, Wang C, Tian W, Lan F, Liang D, et al. A Novel Rhein Derivative: Activation of Rac1/NADPH Pathway Enhances Sensitivity of Nasopharyngeal Carcinoma Cells to Radiotherapy. Cell Signal (2019) 54:35-45. doi: 10.1016/j.cellsig.2018.11.015 
150. Tan S, Yi P, Wang H, Xia L, Han Y, Wang H, et al. RAC1 Involves in the Radioresistance by Mediating Epithelial-Mesenchymal Transition in Lung Cancer. Front Oncol (2020) 10:649. doi: 10.3389/fonc.2020.00649

151. Skvortsov S, Dudas J, Eichberger P, Witsch-Baumgartner M, Loeffler-Ragg J, Pritz C, et al. Racl as a Potential Therapeutic Target for ChemoRadioresistant Head and Neck Squamous Cell Carcinomas (HNSCC). $\mathrm{Br} \mathrm{J}$ Cancer (2014) 110(11):2677-87. doi: 10.1038/bjc.2014.221

152. Yan Y, Hein AL, Etekpo A, Burchett KM, Lin C, Enke CA, et al. Inhibition of RAC1 Gtpase Sensitizes Pancreatic Cancer Cells to Gamma-Irradiation. Oncotarget (2014) 5(21):10251-70. doi: 10.18632/oncotarget.2500

153. Yoon C, Cho SJ, Chang KK, Park DJ, Ryeom SW, Yoon SS. Role of Rac1 Pathway in Epithelial-to-Mesenchymal Transition and Cancer Stem-Like Cell Phenotypes in Gastric Adenocarcinoma. Mol Cancer Res (2017) 15 (8):1106-16. doi: 10.1158/1541-7786.MCR-17-0053

154. Dokmanovic M, Hirsch DS, Shen Y, Wu WJ. Racl Contributes to Trastuzumab Resistance of Breast Cancer Cells: Racl as a Potential Therapeutic Target for the Treatment of Trastuzumab-Resistant Breast Cancer. Mol Cancer Ther (2009) 8 (6):1557-69. doi: 10.1158/1535-7163.MCT-09-0140

155. Owen DH, Konda B, Sipos J, Liu T, Webb A, Ringel MD, et al. KRAS G12V Mutation in Acquired Resistance to Combined BRAF and MEK Inhibition in Papillary Thyroid Cancer. J Natl Compr Canc Netw (2019) 17(5):409-13. doi: 10.6004 /jnccn.2019.7292

156. Berron-Ruiz L. [Immunological Alterations in Common Variable Immunodeficiency]. Rev Alerg Mex (2017) 64(1):87-108. doi: 10.29262/ ram.v64i1.227

157. An Y, Adams JR, Hollern DP, Zhao A, Chang SG, Gams MS, et al. Cdh1 and Pik3ca Mutations Cooperate to Induce Immune-Related Invasive Lobular Carcinoma of the Breast. Cell Rep (2018) 25(3):702-14.e6. doi: 10.1016/ j.celrep.2018.09.056

158. Pohlmann S, Scheu S, Ziegler V, Schupp N, Henninger C, Fritz G. Hepatic Rac1 Gtpase Contributes to Liver-Mediated Basal Immune Homeostasis and LPS-Induced Endotoxemia. Biochim Biophys Acta Mol Cell Res (2018) 1865 (9):1277-92. doi: 10.1016/j.bbamcr.2018.06.007

159. Winge MC, Ohyama B, Dey CN, Boxer LM, Li W, Ehsani-Chimeh N, et al. RAC1 Activation Drives Pathologic Interactions Between the Epidermis and Immune Cells. J Clin Invest (2016) 126(7):2661-77. doi: 10.1172/JCI85738

160. Kurdi AT, Bassil R, Olah M, Wu C, Xiao S, Taga M, et al. Tiam1/Rac1 Complex Controls Il17a Transcription and Autoimmunity. Nat Commun (2016) 7:13048. doi: 10.1038/ncomms13048

161. Li W, Li Y, Guan Y, Du Y, Zhao M, Chen X, et al. TNFAIP8L2/TIPE2 Impairs Autolysosome Reformation Via Modulating the RAC1-MTORC1 Axis. Autophagy (2020), 1-16. doi: 10.1080/15548627.2020.1761748

162. Weichhart T, Saemann MD. The PI3K/Akt/Mtor Pathway in Innate Immune Cells: Emerging Therapeutic Applications. Ann Rheum Dis (2008) 67 Suppl 3:iii70-4. doi: 10.1136/ard.2008.098459

163. Khanal P, Chikhale R, Dey YN, Pasha I, Chand S, Gurav N, et al. Withanolides From Withania Somnifera as an Immunity Booster and Their Therapeutic Options Against COVID-19. J Biomol Struct Dyn (2021) 1-14. doi: 10.1080/07391102.2020.1869588

164. Vu HL, Rosenbaum S, Purwin TJ, Davies MA, Aplin AE. RAC1 P29S Regulates PD-L1 Expression in Melanoma. Pigment Cell Melanoma Res (2015) 28(5):590-8. doi: 10.1111/pcmr.12392

165. Ramsay AG, Evans R, Kiaii S, Svensson L, Hogg N, Gribben JG. Chronic Lymphocytic Leukemia Cells Induce Defective LFA-1-Directed T-Cell Motility by Altering Rho Gtpase Signaling That is Reversible With Lenalidomide. Blood (2013) 121(14):2704-14. doi: 10.1182/blood-2012-08-448332

166. Gastonguay A, Berg T, Hauser AD, Schuld N, Lorimer E, Williams CL. The Role of Racl in the Regulation of NF-Kappab Activity, Cell Proliferation, and Cell Migration in Non-Small Cell Lung Carcinoma. Cancer Biol Ther (2012) 13(8):647-56. doi: 10.4161/cbt.20082

167. Karpel-Massler G, Westhoff MA, Zhou S, Nonnenmacher L, Dwucet A, Kast $\mathrm{RE}$, et al. Combined Inhibition of HER1/EGFR and RAC1 Results in a Synergistic Antiproliferative Effect on Established and Primary Cultured Human Glioblastoma Cells. Mol Cancer Ther (2013) 12(9):1783-95. doi: 10.1158/1535-7163.MCT-13-0052

168. Gao Y, Dickerson JB, Guo F, Zheng J, Zheng Y. Rational Design and Characterization of a Rac Gtpase-Specific Small Molecule Inhibitor. Proc Natl Acad Sci USA (2004) 101(20):7618-23. doi: 10.1073/pnas.0307512101
169. Pickering KA, Gilroy K, Cassidy JW, Fey SK, Najumudeen AK, Zeiger LB, et al. A RAC-GEF Network Critical for Early Intestinal Tumourigenesis. Nat Commun (2021) 12(1):56. doi: 10.1038/s41467-020-20255-4

170. Zheng C, Wu X, Zeng R, Lin L, Xu L, Li E, et al. Computational Prediction of Hot Spots and Binding Site of Inhibitor NSC23766 on Rac1 Binding With Tiam1. Front Chem (2020) 8:625437. doi: 10.3389/fchem.2020.625437

171. Li D, Ding X, Xie M, Huang Z, Han P, Tian D, et al. CAMSAP2-Mediated Noncentrosomal Microtubule Acetylation Drives Hepatocellular Carcinoma Metastasis. Theranostics (2020) 10(8):3749-66. doi: 10.7150/thno.42596

172. Chang CY, Lin SC, Su WH, Ho CM, Jou YS. Somatic LMCD1 Mutations Promoted Cell Migration and Tumor Metastasis in Hepatocellular Carcinoma. Oncogene (2012) 31(21):2640-52. doi: 10.1038/onc.2011.440

173. Montalvo-Ortiz BL, Castillo-Pichardo L, Hernandez E, Humphries-Bickley T, De la Mota-Peynado A, Cubano LA, et al. Characterization of Ehop-016, Novel Small Molecule Inhibitor of Rac Gtpase. J Biol Chem (2012) 287 (16):13228-38. doi: 10.1074/jbc.M111.334524

174. Castillo-Pichardo L, Humphries-Bickley T, De La Parra C, Forestier-Roman I, Martinez-Ferrer M, Hernandez E, et al. The Rac Inhibitor Ehop-016 Inhibits Mammary Tumor Growth and Metastasis in a Nude Mouse Model. Transl Oncol (2014) 7(5):546-55. doi: 10.1016/j.tranon.2014.07.004

175. Boettner B, Van Aelst L. The Role of Rho Gtpases in Disease Development. Gene (2002) 286(2):155-74. doi: 10.1016/s0378-1119(02)00426-2

176. Jiang ZB, Ma BQ, Feng Z, Liu SG, Gao P, Yan HT. Mir-365 Inhibits the Progression of Gallbladder Carcinoma and Predicts the Prognosis of Gallbladder Carcinoma Patients. Cell Cycle (2021) 20(3):308-19. doi: 10.1080/15384101.2021.1874694

177. Shutes A, Onesto C, Picard V, Leblond B, Schweighoffer F, Der CJ. Specificity and Mechanism of Action of EHT 1864, a Novel Small Molecule Inhibitor of Rac Family Small Gtpases. J Biol Chem (2007) 282(49):35666-78. doi: 10.1074/jbc.M703571200

178. Onesto C, Shutes A, Picard V, Schweighoffer F, Der CJ. Characterization of EHT 1864, a Novel Small Molecule Inhibitor of Rac Family Small Gtpases. Methods Enzymol (2008) 439:111-29. doi: 10.1016/S0076-6879(07)00409-0

179. Hampsch RA, Shee K, Bates D, Lewis LD, Desire L, Leblond B, et al. Therapeutic Sensitivity to Rac Gtpase Inhibition Requires Consequential Suppression of Mtorc1, AKT, and MEK Signaling in Breast Cancer. Oncotarget (2017) 8(13):21806-17. doi: 10.18632/oncotarget.15586

180. Kai Y, Motegi M, Suzuki Y, Takeuchi H, Harada Y, Sato F, et al. UpRegulation of Rac1 in the Bronchial Smooth Muscle of Murine Experimental Asthma. Basic Clin Pharmacol Toxicol (2019) 125(1):8-15. doi: 10.1111/ bcpt.13204

181. Sakai H, Kai Y, Sato K, Ikebe M, Chiba Y. Rac1 Modulates G-ProteinCoupled Receptor-Induced Bronchial Smooth Muscle Contraction. Eur J Pharmacol (2018) 818:74-83. doi: 10.1016/j.ejphar.2017.10.032

182. Li B, Yu Q, Wang R, Gratzke C, Wang X, Spek A, et al. Inhibition of Female and Male Human Detrusor Smooth Muscle Contraction by the Rac Inhibitors EHT1864 and NSC23766. Front Pharmacol (2020) 11:409. doi: 10.3389/fphar.2020.00409

183. Wang Y, Kunit T, Ciotkowska A, Rutz B, Schreiber A, Strittmatter F, et al. Inhibition of Prostate Smooth Muscle Contraction and Prostate Stromal Cell Growth by the Inhibitors of Rac, NSC23766 and EHT1864. Br J Pharmacol (2015) 172(11):2905-17. doi: 10.1111/bph.13099

184. Wang R, Yu Q, Wang X, Li B, Ciotkowska A, Rutz B, et al. Rac1 Silencing, NSC23766 and EHT1864 Reduce Growth and Actin Organization of Bladder Smooth Muscle Cells. Life Sci (2020) 261:118468. doi: 10.1016/ j.lfs. 2020.118468

185. Liu H, Li L, Chen Z, Song Y, Liu W, Gao G, et al. S1PR2 Inhibition Attenuates Allergic Asthma Possibly by Regulating Autophagy. Front Pharmacol (2020) 11:598007. doi: 10.3389/fphar.2020.598007

186. Yu Q, Gratzke C, Wang Y, Wang X, Li B, Strittmatter F, et al. New Strategies for Inhibition of Non-Adrenergic Prostate Smooth Muscle Contraction by Pharmacologic Intervention. Prostate (2019) 79(7):746-56. doi: 10.1002/ pros. 23780

187. Dilasser F, Rose L, Hassoun D, Klein M, Rousselle M, Brosseau C, et al. Essential Role of Smooth Muscle Rac1 in Severe Asthma-Associated Airway Remodelling. Thorax (2021) 76(4):326-34. doi: 10.1136/thoraxjnl-2020-216271

188. Cardama GA, Gonzalez N, Ciarlantini M, Gandolfi Donadio L, Comin MJ, Alonso DF, et al. Proapoptotic and Antiinvasive Activity of Racl Small 
Molecule Inhibitors on Malignant Glioma Cells. Onco Targets Ther (2014) 7:2021-33. doi: 10.2147/OTT.S67998

189. Gonzalez N, Cardama GA, Chinestrad P, Robles-Valero J, Rodriguez-Fdez S, Lorenzo-Martin LF, et al. Computational and in Vitro Pharmacodynamics Characterization of 1A-116 Rac1 Inhibitor: Relevance of Trp56 in Its Biological Activity. Front Cell Dev Biol (2020) 8:240. doi: 10.3389/fcell.2020.00240

190. Cardama GA, Comin MJ, Hornos L, Gonzalez N, Defelipe L, Turjanski AG, et al. Preclinical Development of Novel Rac1-GEF Signaling Inhibitors Using a Rational Design Approach in Highly Aggressive Breast Cancer Cell Lines. Anticancer Agents Med Chem (2014) 14(6):840-51. doi: 10.2174/ 18715206113136660334

191. Cabrera M, Echeverria E, Lenicov FR, Cardama G, Gonzalez N, Davio C, et al. Pharmacological Rac1 Inhibitors With Selective Apoptotic Activity in Human Acute Leukemic Cell Lines. Oncotarget (2017) 8(58):98509-23. doi: 10.18632/oncotarget.21533

192. Ciarlantini MS, Barquero A, Bayo J, Wetzler D, Dodes Traian MM, Bucci HA, et al. Development of an Improved Guanidine-Based Rac1 Inhibitor With in Vivo Activity Against Non-Small Cell Lung Cancer. ChemMedChem (2020) 16(6):1011-21. doi: 10.1002/cmdc.202000763

193. Bayo J, Fiore EJ, Dominguez LM, Cantero MJ, Ciarlantini MS, Malvicini M, et al. Bioinformatic Analysis of RHO Family of Gtpases Identifies RAC1 Pharmacological Inhibition as a New Therapeutic Strategy for Hepatocellular Carcinoma. Gut (2020). doi: 10.1136/gutjnl-2020-321454

194. Martin H, Mali RS, Ma P, Chatterjee A, Ramdas B, Sims E, et al. Pak and Rac Gtpases Promote Oncogenic KIT-Induced Neoplasms. J Clin Invest (2013) 123(10):4449-63. doi: 10.1172/JCI67509

195. Rosenblatt AE, Garcia MI, Lyons L, Xie Y, Maiorino C, Desire L, et al. Inhibition of the Rho Gtpase, Rac1, Decreases Estrogen Receptor Levels and is a Novel Therapeutic Strategy in Breast Cancer. Endocr Relat Cancer (2011) 18(2):207-19. doi: 10.1677/ERC-10-0049

196. Gonzalez N, Cardama GA, Comin MJ, Segatori VI, Pifano M, Alonso DF, et al. Pharmacological Inhibition of Rac1-PAK1 Axis Restores Tamoxifen Sensitivity in Human Resistant Breast Cancer Cells. Cell Signal (2017) 30:154-61. doi: 10.1016/j.cellsig.2016.12.002

197. Desire L, Bourdin J, Loiseau N, Peillon H, Picard V, De Oliveira C, et al. RAC1 Inhibition Targets Amyloid Precursor Protein Processing by GammaSecretase and Decreases Abeta Production in Vitro and in Vivo. J Biol Chem (2005) 280(45):37516-25. doi: 10.1074/jbc.M507913200

198. Kawarazaki W, Nagase M, Yoshida S, Takeuchi M, Ishizawa K, Ayuzawa N, et al. Angiotensin II- and Salt-Induced Kidney Injury Through Rac1Mediated Mineralocorticoid Receptor Activation. J Am Soc Nephrol (2012) 23(6):997-1007. doi: 10.1681/ASN.2011070734
199. Ziegler V, Henninger C, Simiantonakis I, Buchholzer M, Ahmadian MR, Budach W, et al. Rho Inhibition by Lovastatin Affects Apoptosis and DSB Repair of Primary Human Lung Cells in Vitro and Lung Tissue in Vivo Following Fractionated Irradiation. Cell Death Dis (2017) 8(8):e2978. doi: $10.1038 /$ cddis.2017.372

200. Dutting S, Heidenreich J, Cherpokova D, Amin E, Zhang SC, Ahmadian MR, et al. Critical Off-Target Effects of the Widely Used Rac1 Inhibitors NSC23766 and EHT1864 in Mouse Platelets. J Thromb Haemost (2015) 13 (5):827-38. doi: 10.1111/jth.12861

201. Xie W, Zhang W, Sun M, Lu C, Shen Y. Deacetylmycoepoxydiene is an Agonist of Racl, and Simultaneously Induces Autophagy and Apoptosis. Appl Microbiol Biotechnol (2018) 102(14):5965-75. doi: 10.1007/s00253-0189058-6

202. Oprea TI, Sklar LA, Agola JO, Guo Y, Silberberg M, Roxby J, et al. Novel Activities of Select NSAID R-Enantiomers Against Rac1 and Cdc42 Gtpases. PloS One (2015) 10(11):e0142182. doi: 10.1371/journal.pone.0142182

203. Grimes MM, Kenney SR, Dominguez DR, Brayer KJ, Guo Y, WandingerNess A, et al. The R-Enantiomer of Ketorolac Reduces Ovarian Cancer Tumor Burden in Vivo. BMC Cancer (2021) 21(1):40. doi: 10.1186/s12885020-07716-1

204. Xu J, Simonelli F, Li X, Spinello A, Laporte S, Torre V, et al. Molecular Mechanisms of the Blockage of Glioblastoma Motility. J Chem Inf Model (2021). doi: 10.1021/acs.jcim.1c00279

205. Kang J, Zhong Y, Tian W, Li J, Li X, Zhai L, et al. A Novel Anthraquinonequinazoline Hybrid 7B Blocks Breast Cancer Metastasis and EMT Via Targeting EGFR and Rac1. Int J Oncol (2021) 58(5):19. doi: 10.3892/ijo.2021.5199

206. Akbar H, Cancelas J, Williams DA, Zheng J, Zheng Y. Rational Design and Applications of a Rac Gtpase-Specific Small Molecule Inhibitor. Methods Enzymol (2006) 406:554-65. doi: 10.1016/S0076-6879(06)06043-5

Conflict of Interest: The authors declare that the research was conducted in the absence of any commercial or financial relationships that could be construed as a potential conflict of interest.

Copyright $\odot 2021$ Liang, Oyang, Rao, Han, Luo, Yi, Lin, Xia, Hu, Tan, Tang, Pan, Tang, Zhou and Liao. This is an open-access article distributed under the terms of the Creative Commons Attribution License (CC BY). The use, distribution or reproduction in other forums is permitted, provided the original author(s) and the copyright owner(s) are credited and that the original publication in this journal is cited, in accordance with accepted academic practice. No use, distribution or reproduction is permitted which does not comply with these terms. 


\section{GLOSSARY}

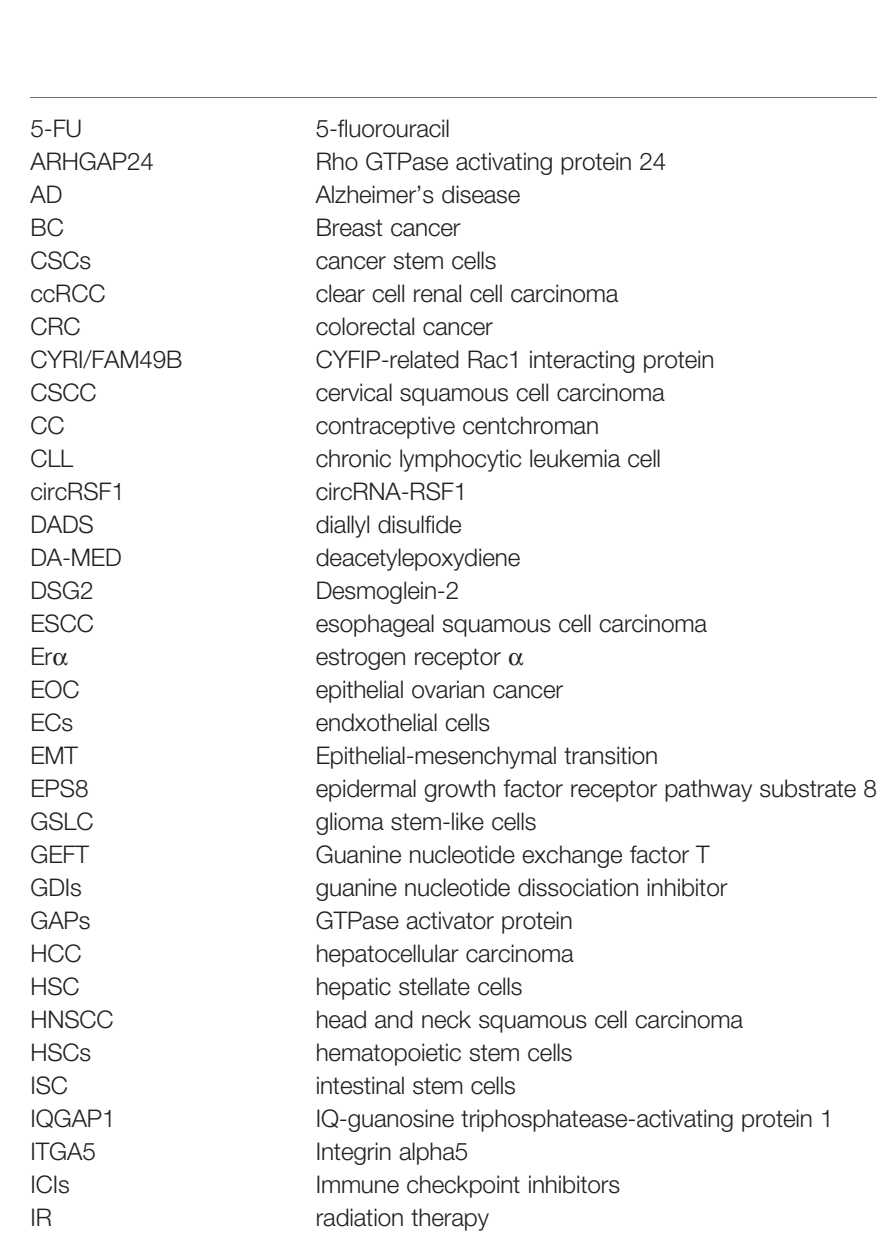

(Continued)
Continued

\begin{tabular}{|c|c|}
\hline IL17A & interleukin 17A \\
\hline LIMK1 & LIM kinase 1 \\
\hline LFA-1 & Iymphocyte function-associated antigen-1 \\
\hline MET & mesenchymal-epithelial transformation \\
\hline M1-Exos & M1-type macrophage-derived exosomes \\
\hline $\mathrm{NAC}$ & neoadjuvant chemotherapy \\
\hline NPC & nasopharyngeal carcinoma \\
\hline NSCLC & non-small cell lung cancer \\
\hline NBS & nucleotide-binding site \\
\hline OIP5 & OPA interacting protein- 5 \\
\hline OSCC & oral squamous cell carcinoma \\
\hline OXA & oxaliplatin \\
\hline PPP & pentose phosphate pathway \\
\hline PBR & multi-base region \\
\hline PGC & primary gallbladder cancer \\
\hline PKC- $\zeta$ & protein kinase $\mathrm{C}-\zeta$ \\
\hline PAKs & p21 activated kinase \\
\hline pp70s6k & The 70 kDa S6 kinase complexes \\
\hline PLS1 & Plastin1 \\
\hline PTP $\sigma$ & protein tyrosine phosphatase-sigma \\
\hline PLPPR1 & phospholipid phosphatase-related protein 1 \\
\hline RIII & radiation-induced intestinal injury \\
\hline RILD & radiation-induced liver disease \\
\hline Rac1 & RAS-related C3 botulinum toxin substrate 1 \\
\hline RCC & renal cell carcinoma \\
\hline RCC2 & regulation of chromosome condensation 2 \\
\hline ROCK2 & Rho-linked kinase 2 \\
\hline RMS & rhabdomyosarcoma \\
\hline Sema3F & semaphorin-3F \\
\hline Sema3C & Semaphorin-3C \\
\hline S1PR1 & Sphingosine-1 phosphate receptor 1 \\
\hline SDF- $1 \alpha$ & stromal cell-derived factor $1-\alpha$ \\
\hline SCC & squamous cell carcinoma \\
\hline Tiam1 & T lymphoma invasion and metastasis protein 1 \\
\hline TNBC & triple-negative breast cancer \\
\hline TNFAIP8L2/TIPE2 & tumor necrosis factor, alpha-induced protein 8-like 2 \\
\hline UA & Urobilin A \\
\hline VEGF & vascular endothelial growth factor \\
\hline VEGFR & vascular endothelial growth factor receptor \\
\hline
\end{tabular}

